Article

\title{
Mitigating Urban Visual Pollution through a Multistakeholder Spatial Decision Support System to Optimize Locational Potential of Billboards
}

\author{
Khydija Wakil $^{1, *}$, Ali Tahir ${ }^{2}{ }^{(}$, , Muhammad Qadeer ul Hussnain ${ }^{1}\left(D\right.$, Abdul Waheed ${ }^{1}$ and Raheel Nawaz ${ }^{3}(1)$ \\ 1 Department of Urban \& Regional Planning, National University of Sciences \& Technology (NUST), \\ Islamabad 44000, Pakistan; plannerqadeer.urp@nit.nust.edu.pk (M.Q.u.H.); drwaheed@nit.nust.edu.pk (A.W.) \\ 2 Institute of Geographical Information Systems, National University of Sciences \& Technology (NUST), \\ Islamabad 44000, Pakistan; ali.tahir@igis.nust.edu.pk \\ 3 Department of Operations, Technology, Events and Hospitality Management, \\ Manchester Metropolitan University, Manchester M15 6BH, UK; r.nawaz@mmu.ac.uk \\ * Correspondence: khydijawakeel.urp@nit.nust.edu.pk; Tel.: +92-333-6260791
}

check for updates

Citation: Wakil, K.; Tahir, A.; Hussnain, M.Q.u.; Waheed, A.; Nawaz, R. Mitigating Urban Visual Pollution through a Multistakeholder Spatial Decision Support System to Optimize Locational Potential of Billboards. ISPRS Int. J. Geo-Inf. 2021, 10, 60. https://doi.org/10.3390/ ijgi10020060

Academic Editors: Timothy Nyerges and Wolfgang Kainz

Received: 15 December 2020

Accepted: 27 January 2021

Published: 1 February 2021

Publisher's Note: MDPI stays neutral with regard to jurisdictional claims in published maps and institutional affiliations.

Copyright: (c) 2021 by the authors. Licensee MDPI, Basel, Switzerland. This article is an open access article distributed under the terms and conditions of the Creative Commons Attribution (CC BY) license (https:// creativecommons.org/licenses/by/ $4.0 /)$.

\begin{abstract}
Urban visual pollution is increasingly affecting the built-up areas of the rapidly urbanizing planet. Outdoor advertisements are the key visual pollution objects affecting the visual pollution index and revenue generation potential of a place. Current practices of uninformed and uncontrolled outdoor advertising (especially billboards) impairs effective control of visual pollution in developing countries. Improving this can result in over $20 \%$ reduction of visual pollution. This article presents a spatial decision support system (SDSS) to facilitate all the stakeholders (development control authorities, advertisers, billboard owners, and the public) in balancing the optimal positioning of billboards under the governing regulations. In terms of its technical implementation, SDSS is based on well-known geospatial open source technologies and uses an analytical hierarchy process AHP-inspired approach in spatial decision-making. It can help users through its category-specific user interface to identify potential sites to position new billboards and the selection of boards from existing sites based on a wide variety of characteristics. The observations of all stakeholders have been recorded through panel feedback to assess the system's initial effectiveness. The proposed system has been found functional in identifying hot spots for the focused management and exploration of the best suitable sites for new billboards. So, it helps the advertising agencies, urban authorities, and city councils in better planning and management of existing billboard locations to optimize revenue and improve urban aesthetics. The system can be replicated in other countries irrespective of spatial boundaries by incorporating jurisdictional rules and regulations.
\end{abstract}

Keywords: billboards; spatial decision support system (SDSS); visual pollution, optimal location; mobile-based data collection; open data kit (ODK); billboards management system

\section{Introduction}

Rapid urbanization has affected visual pollution, deteriorating the quality of life in urban centres. Researchers have recently started exploring various dimensions of this new form of pollution [1-4]. Wakil et al. have labelled the "pollutants" as "Visual Pollution Objects (VPOs)" to refer to all kinds of manmade features along with their physical characteristics (placement, appearance, size, color, view and functional hindrance) that affect the visual quality of urban surroundings [5]. Portella has listed VPOs in the context of developed countries [1], while Sivaramanan [6] and Wakil [7] have identified contextual VPOs in developing countries. In their recent works, Wakil et al. have identified thirty-nine VPOs and ranked them based on contribution to the Visual Pollution Index (VPI), which is a scale of measuring visual pollution at a given node. After McMahon declared billboards to be "litter on a stick", most scholars believe that outdoor advertisements and billboards are the most significant sources of urban visual pollution [8]. Wakil et al. estimate that 
outdoor advertisements and billboards contribute to $20.6 \%$ of the spatial visual pollution in a typical urban setting of a developing country. They are blamed for being the key source of highway crashes, mental health implications and cultural devastation [9-13]. A group of researchers believe that the lack of control and management of billboards and hoardings has destroyed the visual-physical environment of our cities $[5,7,12,14-16]$. With higher locational concentration, unsuitable sizes, varying heights, unbalanced colors and poor construction practices, they damage the socio-physical environment in urban centres [17].

On the other hand, billboards and hoardings are a considerably large revenue source for controlling agencies and their owners and advertisers [13]. Additionally, as a medium of communication, billboards are encouraged for advertising due to visibility, revenue generation, media effectiveness and tangible response [18]. In Lahore, Pakistan, billboards' tax income was $75 \%$ of the total annual income of the municipal committee. Taylor has documented the role of billboards in the US economy [19]. Hence, a complete ban on outdoor advertisements is not a viable management option as it has economic implications.

Globally, various modes of regulatory response exist to handle outdoor advertisements. They include from a complete ban, mild management and loosely-coupled control. In terms of regulations, São Paulo has adopted a "clean city law" imposing a complete ban on billboards [20]. Simultaneously, others have tried to regulate this phenomenon in terms of placement, size, color and contents. Planning authorities in developing countries like Pakistan are struggling with the management of billboards and hoardings in urban areas and are introducing regulatory frameworks for effective management [17,21-26]. However, the regulating agencies lack a scientific approach, such as using spatial analysis to identify problem areas.

In developing countries, billboards are a necessary evil for controlling authorities but cash cows for advertisers. Advertising agencies hunt for locations offering more prolonged exposure and higher traffic in relevant communities. Currently, billboard choice selection is based on an advertising agency's marketing staff's judgment rather than any decision support system offering information-based scenarios. In such circumstances, decision support systems are often handy to resolve complex preference problems.

Regulatory bodies require support in identifying areas with a higher locational density of billboards to regulate future installation permissions. Together, advertisers need to identify sites offering good exposure to a maximum audience in relevant communities. This is important to highlight that the intended stakeholders such as the advertisement agencies (more precisely "media communication groups" or "media houses") and controlling authorities (urban planners) have different objectives and competing requirements in out of home media management which has not been previously managed through a single interface spatial decision support system (SDSS). Hence, the SDSS is proposed as a bridge between urban space stakeholders. This study develops an SDSS which supports relevant stakeholders in their decisions by providing actionable information. It could help manage and control billboards such that maximum financial potential within the regulatory limitations can be exploited.

This study presents a novel tool for the relevant stakeholders where the SDSS involves inventories of existing billboards and hoardings and supporting spatial data of the case city through primary and secondary data collection. The SDSS aims to (a) assist government bodies in regulating the location of billboards by maintaining linear density, size, and height of installations in the light of relevant regulations; (b) assist billboard owners in selecting optimal sites for the installation of new billboards and hoardings; (c) help advertisers in selecting suitable sites for an advertisement campaign based on the billboard site characteristics and neighborhood demographics.

\section{Related Work}

Keywords and semantic searches have been used for the scoping review on the development of literature about visual pollution in the major global databases including "Urban studies abstracts via EBSCO", "Art and Architecture Complete", "ScienceDirect", 
"Web of Science", "SAGE Research Methods Online", "Scopus", "Google Scholar", "APAFT: Australian public affairs (full text) via Informit", "CrossRef" and "Microsoft Academic". The results show an increase in the publications on the subject in the last ten years. All the published literature in the English language has been manually cleaned to remove duplicates, and a final list of 248 published works has been used for further study. The current state of research on the subject can be categorized into six major areas;

(a) Conceptualization: this group of research works revolves around defining the terms and its various aspects [6,15,27-39].

(b) Description of visual pollution: this group of research works explain the existence of visual pollution phenomena in different areas and contexts [2,6,40-65].

(c) Pollution ingredients: the research work that describes the various physical objects and their conditions which result in the visual pollution [14,16,66-86].

(d) Application: this category of research explains the application of the visual pollution concept in real-world [3,87-100].

(e) Assessment/measurement/quantification: documents the methods of assessing, measuring or quantifying various aspects of visual pollution $[5,7,12,17,101-124]$.

(f) Regulation/mitigation/control: describes various methods of regulating, mitigating or controlling visual pollution or its pollutants in various countries [20,86,125-142].

In the past few years, research has demonstrated the application of geospatial technologies to study outdoor advertisements. Developed countries provide few examples where GIS-based tools have been implemented to identify optimal locations for outdoor advertisements $[143,144]$. Haidu et al. have worked on the spatial dimension for optimizing advertisements [145]. They believed that advertisements' effectiveness in any area depends on demographics, socio-economic and educational characteristics, and infrastructure.

Luke et al. have applied GIS for explaining the spatial aspects of tobacco billboards in St Louis [146]. They have implemented spatial analysis to quantify the extent to which tobacco companies were placing billboards close to minority neighborhoods and schools. Similarly, Hillier et al. have noticed and explained the clustering of unhealthy outdoor advertisements around child-serving institutions [147]. He emphasized the need for regulatory provisions to keep outdoor advertisement boards' locations away for such institutions. In Nigeria, private companies have maintained billboards' spatial databases for the advertising industry (Spatial Technologies limited 2011). Likewise, in the USA, Europe and Canada, service providers have been using demographic data, traffic flow, elevation and exposure data for deciding the best locations and return on investment from outdoor advertisements [148]. Wakil has documented a tool used by planning authorities to identify areas (hot spots) with locational congestion for taking corrective measures [17].

However, most researchers have worked on two extreme ends; GIS utilization to help advertisers make profit versus GIS utilization to help planning agencies eliminate billboards. This research focuses on bridging this divide. It is based on the understanding that a balanced approach can be taken where planning agencies can implement restriction, but at the same time advertisers can identify the best location offering maximum return on investment with full compliance of applicable rules. Resultantly, it will significantly help planning authorities and the advertising industry in countries such as Pakistan. With better management of billboards, cities will have improved visual environments while the information-based advertisement industry will contribute positively to the national economy.

While building SDSS, research has suggested applying task-technology-fit framework (TTF) under such circumstances so that the user needs are well documented for all potential users of the SDSS and system functions can be designed to best match the user requirements. The TTF theory has been extensively applied for establishing a correlation among the SDSS's functional abilities and the demands of the tasks to be performed $[149,150]$. In Pakistan's case, Hussnain et al. has applied TTF to conceptualize and build a GIS-based planning support system for urban planning functions [151,152].

Locational problems are often solved through multicriteria decision making. There are several methods to create the criteria weights, for instance, additive normalization method, 
Eigen-vector method, weighted least-squares method, logarithmic least-squares method, and fuzzy method. Chentao has used multicriteria decision making for site selection along a high-speed railway [153]. Analytical hierarchy process (AHP) is a multicriteria decision-making tool that helps decision-makers choose between alternatives [154-156]. It facilitates a decision-maker dealing with a complex problem with multiple inconsistent and subjective criteria $[157,158]$. In contrast to classical AHP, fuzzy AHP uses fuzzy logic which allows more accuracy on the evaluation of complex decision criteria. Fuzzy logic is preferred while handling imprecise, more complex data, and expressions for humans than the static mathematical equations and laws $[159,160]$.

In different fields such as site selection of restaurant, hotels, shipyards, vehicle gas filling station, highways, airports, railways stations, railway tracts, metro bus stations, waste solid management sites, dumping zones, toll plazas and installation of solar parks or wind turbines, the multicriteria decision-making process has been used in similar situations [161,162]. Beskese et al. have reported the usefulness of fuzzy AHP in site selection of Landfill sites [163]. Noorollahi (2016), used the fuzzy AHP method with geographical location and climate conditions using 11 criteria. His study focused on the land suitability analysis for solar farms [164]. Furthermore, Asakereh (2017) has used the same technique to prioritize Khuzestan province's land in Iran to install solar photovoltaic farms, based on techno-economic and environmental aspects [165].

Similarly, Taibi et al. have experimented combining fuzzy AHP with GIS for an industrial site selection problem [166]. Sasan et al. has demonstrated the use of fuzzy AHP in parking lot site selection. They have justified fuzzy AHP application to solve this problem since parking lot site selection requires multicriteria decision making and this problem requires considering multiple competing factors such as economic value, social acceptability, and environment [167]. Rodney has integrated AHP, fuzzy logic and GIS for optimum site modelling [168]. Di Zio et al. have presented another way to resolve such problems by adopting a new technique, "real-time spatial Delphi". They have appreciated the potential of WebGIS for fast online consultations. In their method, Di Zio et al. present the experts with a geo-questionnaire to place a marker on the map (representing a suitable location) along with attribute questions. The online system calculates and shows a circle representing the convergence of all presented points. As the experts improve their input, the circle keeps on shrinking in the real-time and finally, the most suitable site is selected [169]. This method is advantageous to decide the locational occurrence of existing physical phenomena or a suitable location for future use when most of the knowledge is with the experts. However, in cases when the decision about a location has to be taken based on the predetermined attributes (as in our case; the location is primarily based on the traffic flow, road width, adjacent land use, regulatory binding etc.), AHP is more suitable than the spatial Delphi method.

\section{Materials and Methods}

This research is exploratory and applied in nature, adopting a case study approach to gain an indepth understanding of the subject. It follows a five-step process for developing SDSS; starting with reviewing regulatory documents regarding the control and management of billboards to build the knowledge module. All the prohibitive and primitive conditions associated with the outdoor advertisement of billboards were noted down for conversion into equations usable in the knowledge module of the SDSS. After that, the stakeholders' requirements were documented through focused group discussions with subject matter specialists for task-technology fit framework. The needs so collected were transformed into the design and development of web-based SDSS using open-source tools. The primary data from billboards in the case study area was collected through a mobile-based data collection system to populate the database module. Finally, the SDSS application and utilization assessment for user feedback was conducted. Figure 1 illustrates the methodological framework. 
Review of regulatory provisions to develop the Knowledge Module of SDSS

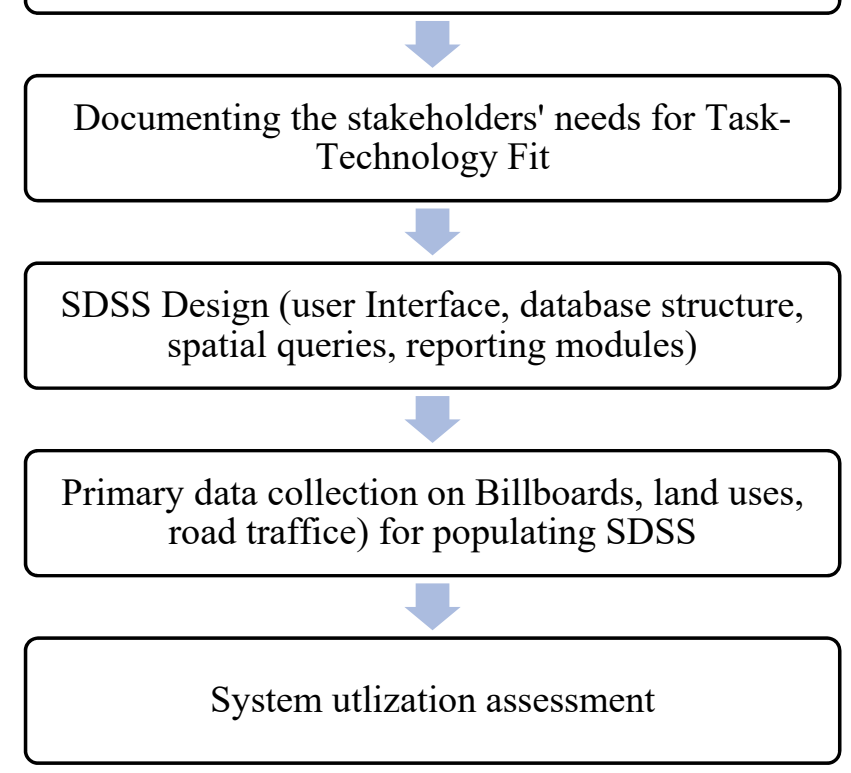

Figure 1. Methodological framework.

\subsection{Case Study Area}

Most of the previous works explore outdoor advertisements at street or block level. In contrast, for the deeper thematic study of the subject, this research has been conducted at a city-scale. Considering the urban dynamics of the developing world, particularly in South Asia, the city of Rawalpindi (the fourth largest city in Pakistan, with more than two million inhabitants at $33.5651^{\circ} \mathrm{N}, 73.0169^{\circ} \mathrm{E}$ ) has been selected as the case study which offers the right mix of land uses, a heterogeneous population, rapid horizontal growth, and the existence of public and private governance mechanisms.

Being a twin city to the country's planned capital, this city (case study) offers a high diversity of land uses, billboards, and multiple controlling authorities as illustrated in Figure 2. The city spans over 300 square kilometres of the area. The control of outdoor advertisement and billboards falls under the Parks and Horticulture Authority, Rawalpindi (PHA) and district governments. In Pakistan's context, outdoor advertisements refer to various forms of ads, including banners, streamers, wall chalking, billboards, hoarding, moving platforms and signs. Hence, these two are dealt with separately in the regulations. Billboards, due to their size, physical location and structure are handled more specifically with guidelines closer to building control in nature. As per its website, the PHA takes responsibility for 180 advertisement board sites while the whole city has witnessed the mushrooming growth of billboards on every roof, wall or pole: Gomez calls this "Billboardization" [170] (See Figure 3). 

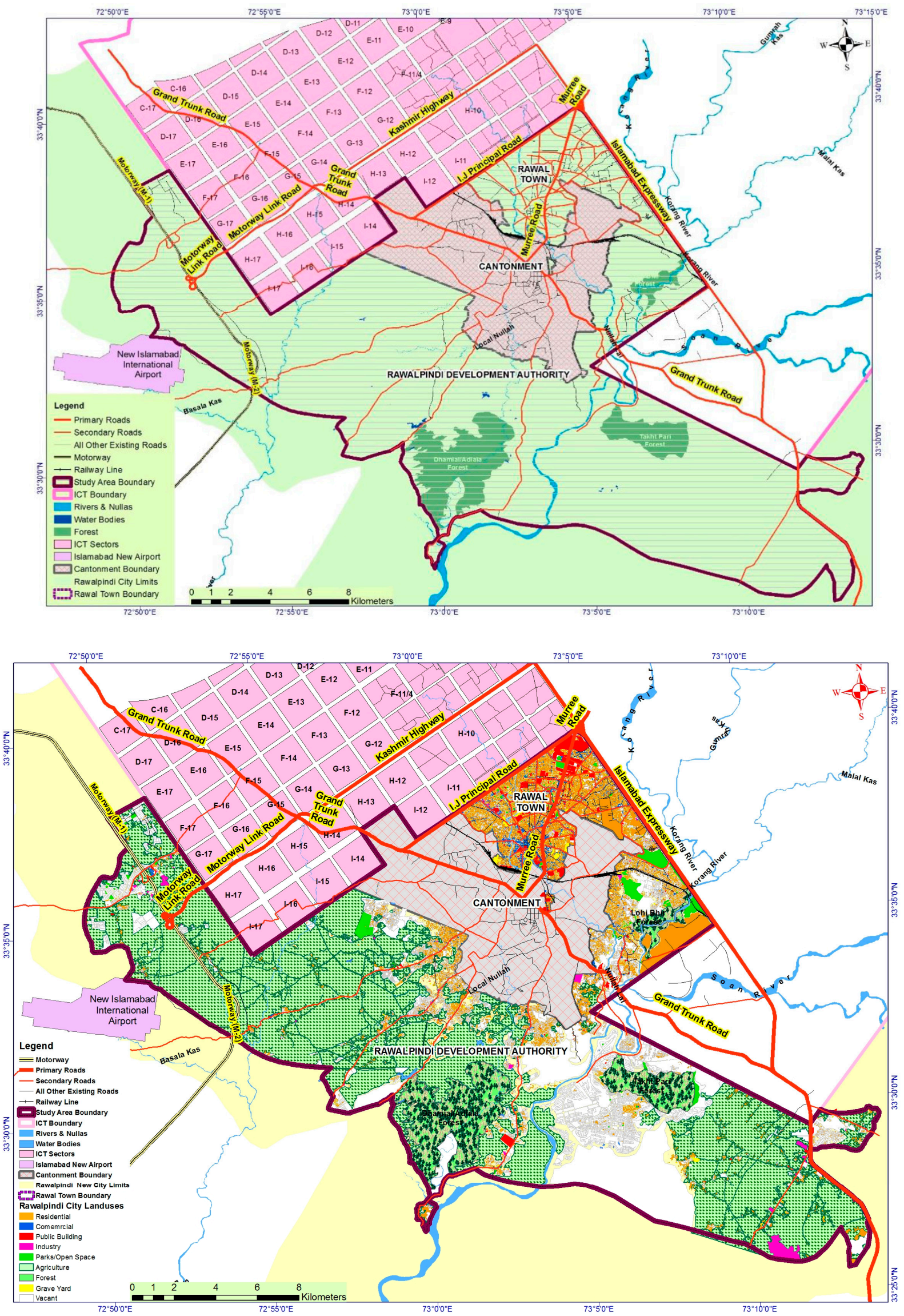

Figure 2. Study area boundary (top) and land use distribution (bottom). 


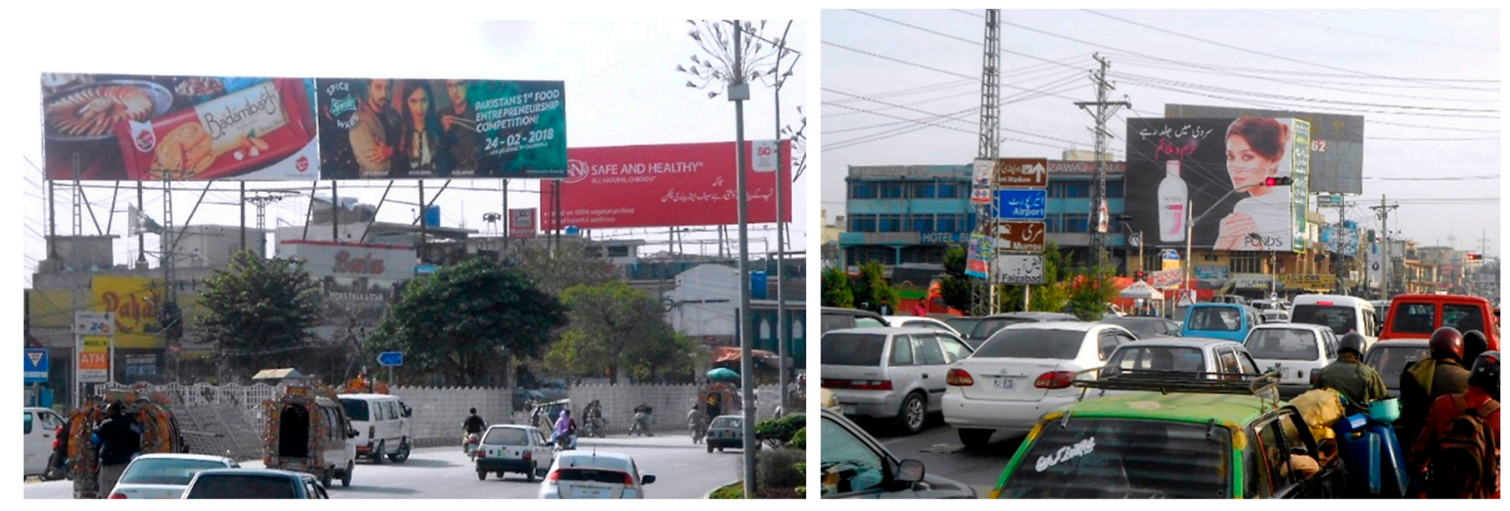

Figure 3. A view of the declared commercial road representing unmanaged growth of billboards.

\subsection{Review of Rules and Regulations Related to the Billboards and Hoarding}

The design of the knowledge module of the SDSS is based on the study of all available and implemented legal documents (bylaws, policies, standard operating procedures, acts) regarding regularization and management of billboards/hoardings. In the case of the research area of study, a comprehensive review of the following regulatory instruments and planning permission guidelines was undertaken:

- Regulations for Outdoor Advertisements and Billboards by Parks and Horticulture Authority (PHA), 2013 [39];

- Punjab Local Government Act, 2013 [171];

- City District Government Faisalabad Advertisement Bylaws, 2013 [23];

- Punjab Outdoor Advertisements and Sign Boards Policy, 2008 by Punjab Housing and Urban Development Department (PHUDD) [24];

- $\quad$ Standard Operation Procedures (SoPs) —Hoarding in Cantonment Areas, July 2011;

- Military Lands and Cantt Hoarding Policy, 2012 [21];

- Advertisement, Signage Bylaws for Karachi 2003;

The regulatory information for development control at any tier mainly consists of permitting or prohibiting outdoor advertisements. In the case of permission, some governing rules are provided related to the locations (and their characteristics) where an outdoor advertisement can be permitted. In the case of this research, regulatory information relevant to permission and/or prohibition has been associated with the road links (polylines) based on the road size category. The study of relevant documents helped extract the list of system attributes required by administrative bodies to regulate billboards. For example, permission for installing the new billboard can be granted if: a. the spacing between two boards varies from $150^{\prime}$ to $250^{\prime}$ based on their location (primary or secondary road, highway) and size $\left(20^{\prime} \times 60^{\prime}\right.$ or $\left.30^{\prime} \times 90^{\prime}\right)$; b the proximity or remoteness of a billboard/ hoarding from certain land-uses. Further, it is used to identify the parameters which control new billboards' placement within the respective agency's jurisdiction area.

\subsection{Mapping the Stakeholders and Their Competing Needs}

This study used a panel of subject matter experts (SMEs) ( $n=15)$ carefully chosen to represent the controlling agencies, advertisers and the community. They were engaged through an online tool to map the stakeholders' needs and requirements from the SDSS. The conceptual diagram of the SDSS was presented to the panel and they were requested to list the most essential needs related to tools, data and processing for the handling of billboards. Furthermore, the SMEs were asked to: (i) note down the information which they expect this SDSS should provide; (ii) list the queries/questions they would like to make through the SDSS; (iii) draw the flow diagram or a sketch of interfaces reflecting 
their mind maps about the SDSS functions. This helped in highlighting the competing and contrasting needs of the stakeholders.

\subsection{Collection of Primary Data on Billboards/Hoardings (Location and Other Attributes of Interest) and Secondary Data}

This stage involved collecting primary data from the field on the spatial location and nonspatial attributes of billboards and hoardings. Some of the critical elements are mentioned in Table 1.

Table 1. Data attributes.

\begin{tabular}{ccc}
\hline Serial Number & Attributes & Categories \\
\hline 1 & GPS location & Latitude, longitude \\
\hline 2 & Type of structure & $\begin{array}{c}\text { Wooden structure, iron structure } \\
\text { monopole, multi post }\end{array}$ \\
\hline 3 & Size of billboard & $\begin{array}{c}\text { Small, } 10 \times 20,20 \times 30,30 \times 40,30 \times 90, \\
\text { Larger }\end{array}$ \\
\hline 5 & Type of message & $\begin{array}{c}\text { Commercial, religious, movie, public service } \\
\text { message, harsh religious / political statement, } \\
\text { political, indecent postures }\end{array}$ \\
\hline 6 & Face directions & Single, double, vertical \\
\hline 7 & Road frontage & In feet, number of lanes and flow direction \\
\hline 8 & Type of advertisement board & $\begin{array}{c}\text { Digital, mechanical, painted, mobile, } \\
\text { poster, other }\end{array}$ \\
\hline 9 & Number of display surfaces & $\begin{array}{c}\text { Single facing, double facing (back to back), v } \\
\text { facing triangle }\end{array}$ \\
\hline 10 & Placement & Stand alone, on-wall, on the rooftop, other \\
\hline 11 & Condition & Broken, leaning, torn off, normal and good \\
\hline 12 & Ownership & Billboard ownership, contact details \\
\hline
\end{tabular}

\subsection{Design of Database Structure for SDSS}

This step included the design and expansion of the spatial database of the SDSS so that it could deal with additional variables, particularly related to advertisers and their choices. Efforts were made to incorporate diverse factors including billboard locations, directions, associated roads, hourly traffic, demography and preferences.

\subsection{Design of User Interface Prototypes and Workflow}

Since the SDSS deals with multiple stakeholders including urban planning agencies, advertisers and board owners, relevant user interfaces have been developed so that the users without urban planning or GIS backgrounds may also make scenarios and adjust decision choices to obtain results. The entity-relationship (ER) diagrams are developed to streamline the workflow.

\subsection{Technology Stack}

The SDSS is based on open-sourced geospatial technologies. The technology stack being used to develop the portal encompasses a front end, LeafletJS (mapping library) used for visualization of billboards and their adjoining areas. The SDSS uses TurfJS (advanced geospatial analysis) for the spatial analysis of the data; in particular, it is used to filter billboards near roads, inside parcel blocks and in close proximity with other billboards. VueJS (JavaScript framework) is the front-end framework, which is being used for building the user interface, with the plugin Vuetify (the design component framework for VueJS) to give the application a material design appearance. The application is running on a VM 
instance on amazon cloud. Open street map (OSM) is used for the background base map, whereas Axios (HTTP client) is being used for data acquisition from the source GeoJSON files. The technology stack is illustrated in Figure 4.

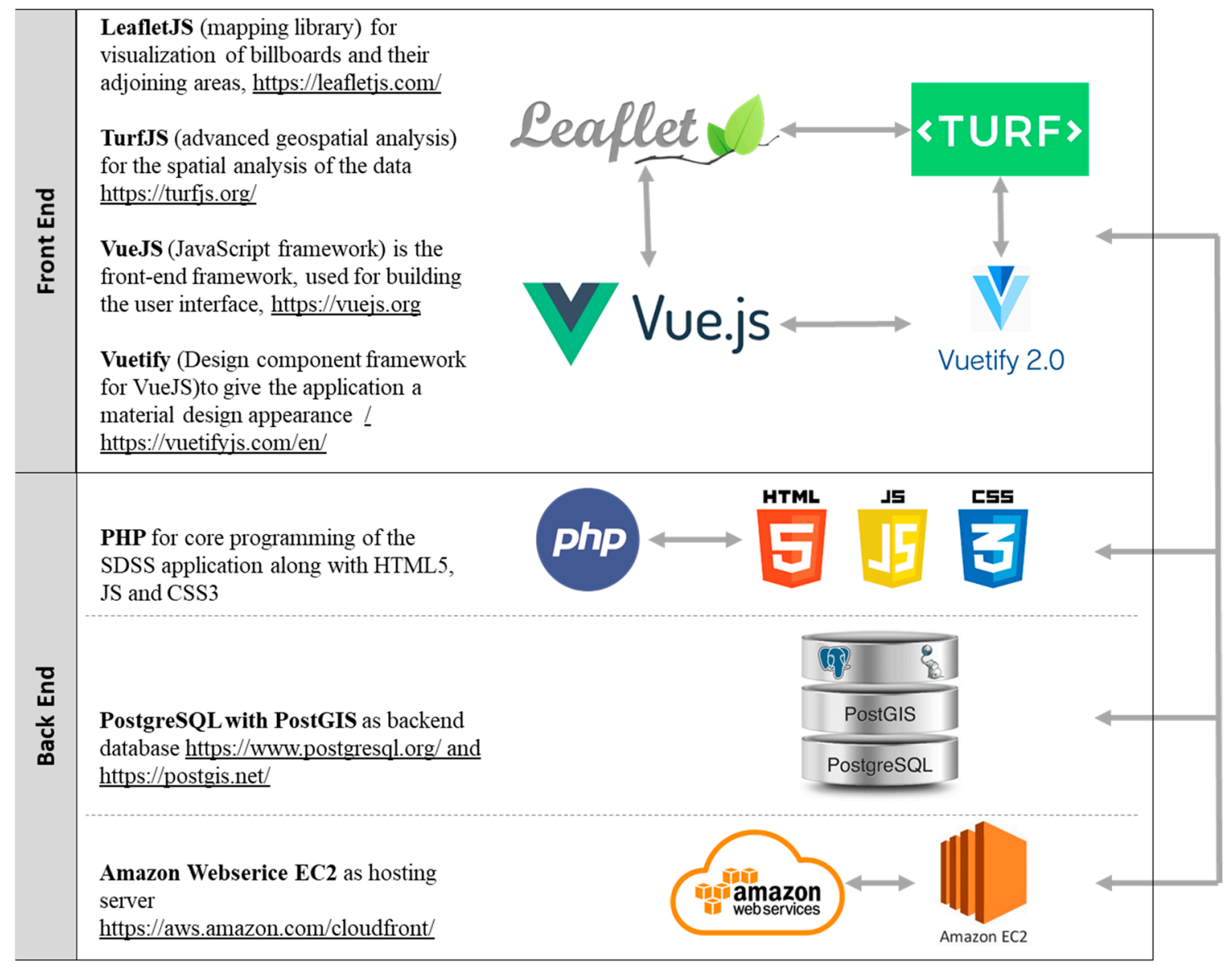

Figure 4. Technology Stack.

\subsection{SDSS Assessment and User Feedback}

After the lab-based development and testing of the SDSS, the panel was briefed about it in a workshop setting where they were oriented about its various functions and were allowed to use the SDSS and share their feedback. The panellists were asked to rank the various functions of the developed system against the initially listed tasks and record their satisfaction at a five-point Likert scale.

\section{Results and Discussion}

Considering the TTF framework, the following conflicting requirements of the user groups can be listed for the SDSS to handle (see Table 2).

There would be two sides of the desired SDSS for billboards: admin and user ends. The admin panel offers the functions for adding and editing data layers, visualization control and knowledge management while the user panel offers various visualization and query function associated to decision making (See Tables 3 and 4). 
Table 2. Requirements of different stakeholders.

\begin{tabular}{|c|c|c|}
\hline Controlling Agency & Advertisers & Community \\
\hline $\begin{array}{l}\text { Need to know: } \\
\text { - The location of installed billboards } \\
\text { along with their attributes (size, } \\
\text { placement, condition, type of } \\
\text { message, faces, advertiser) } \\
\text { - If the billboard has been installed } \\
\text { after approval } \\
\text { - If applicable fees and taxes have } \\
\text { been paid } \\
\text { If the placement complies with the } \\
\text { regulations } \\
\text { If the placement creates a linear } \\
\text { point density of billboards which is } \\
\text { higher than the permissible ratio }\end{array}$ & $\begin{array}{l}\text { Need to know } \\
\text { - The location along with its general } \\
\text { attributes with more focus on } \\
\text { "availability" } \\
\text { - Which potential sites are available } \\
\text { for billboard installation? } \\
\text { The sites owned by other } \\
\text { advertisers and if any of them are } \\
\text { available for rent/sale } \\
\text { - The traffic flow on the adjacent road } \\
\text { - Gross Ratings Points (GRP) for each } \\
\text { - } \quad \text { Eyecific site } \\
\text { - } \quad \text { Daite } \\
\text { Daily Estimated Circulations (DEC) } \\
\text { for each site } \\
\text { What is the demography of the } \\
\text { neighborhood along with } \\
\text { socio-economic class }\end{array}$ & $\begin{array}{l}\text { Need a mechanism to report if a billboard } \\
\text { is causing visual pollution (due to its size, } \\
\text { condition, or type of message) }\end{array}$ \\
\hline
\end{tabular}

Table 3. Functionalities available for different user levels.

\begin{tabular}{|c|c|}
\hline Admin Panel & Users Panel \\
\hline Adding/uploading of layers & $\begin{array}{l}\text { Viewing/visualizing of layers (on/off, feature } \\
\text { identification, measure distance) }\end{array}$ \\
\hline Editing of layers & $\begin{array}{c}\text { Calculating the point density of the billboards by } \\
\text { showing it as a layer }\end{array}$ \\
\hline Visualization control & $\begin{array}{l}\text { Symbolizing (setting the opacity of layers and symbols } \\
\text { by attributes such as classification of billboards by size, } \\
\text { ownership, cost) }\end{array}$ \\
\hline Knowledge management & $\begin{array}{c}\text { Specification of the regularity controls as quantitative } \\
\text { equations }\end{array}$ \\
\hline
\end{tabular}

Table 4. List of queries.

\begin{tabular}{|c|c|}
\hline Query Types. & Query Functions \\
\hline \multirow{3}{*}{$\begin{array}{l}\text { Select queries on attributes } \\
\text { (nonspatial query) }\end{array}$} & $\begin{array}{l}\text { Select billboards where size is of a certain size e.g., larger } \\
\text { than } 90 \mathrm{ft}\end{array}$ \\
\hline & $\begin{array}{l}\text { Select billboards where pole type is for example } \\
\text { "Monopole" }\end{array}$ \\
\hline & Select blocks where land use is "Residential" \\
\hline \multirow{3}{*}{$\begin{array}{l}\text { Spatial queries } \\
\text { (Select objects from a layer based on } \\
\text { their proximity to some other layer.) }\end{array}$} & $\begin{array}{l}\text { Select billboards which are within " } x \text { " meters of a } \\
\text { selected road }\end{array}$ \\
\hline & Select billboard which is within " $\mathrm{x}$ " of parcel block \\
\hline & $\begin{array}{l}\text { Select billboards which are within " } x \text { " meters of a point on } \\
\text { a map }\end{array}$ \\
\hline
\end{tabular}

The following two types of queries along with subqueries are also incorporated in the system:

This study uses a variant of the AHP technique for its core computations while solving the selection problem. Though the overall process is driven and inspired by the workflow of traditional AHP, the variant is significantly different. In our case, the determination 
of the criteria for selecting locations for billboards is highly likely to be affected by the expert opinions and the conditions of the decision-making platform. As a result, the deterministic scale or crisp values can lead to misleading consequences. For example, some stakeholders want bigger sized screens for advertising, while others may want to acquire local citizens' attention based on social class. Such circumstances create fuzziness in the decision-making process.

In the traditional AHP method, each actor/expert evaluates all the hierarchy criteria and alternatives, while in our case every single-user selects a criterion and then makes a pairwise comparison only for the alternatives under that criterion, which distinguishes the method from AHP. For pairwise comparison, a fully connected hierarchy is a key point of the traditional AHP method. However, it is not valid in our case, for example, to do a pairwise comparison between "Restricted" and "Allowed" under the criterion "Size of Billboard". In our approach, the user chooses a criterion. However, in the general AHP method, this is not so, because all the criteria must be compared pairwise. Despite its procedural matching with AHP, our method reflects a sequence where:

- Every single user selects a criterion and then makes the pairwise comparison only for the alternatives under it, and does not evaluate the other alternatives;

- Some alternatives are specific for a given criterion but not for the others;

- The elements of the hierarchy are not fully connected;

- The criteria are not compared pairwise;

- There is no weighting system of the criteria and alternatives;

- There is no estimate of the inconsistency of the matrices.

Figures 5 and 6 illustrate the main interface of the SDDS portal with attribute selection being made with the aid of filters. There is also an option to select different data layers (roads, land parcels), and detailed parameters are displayed upon clicking any billboard.

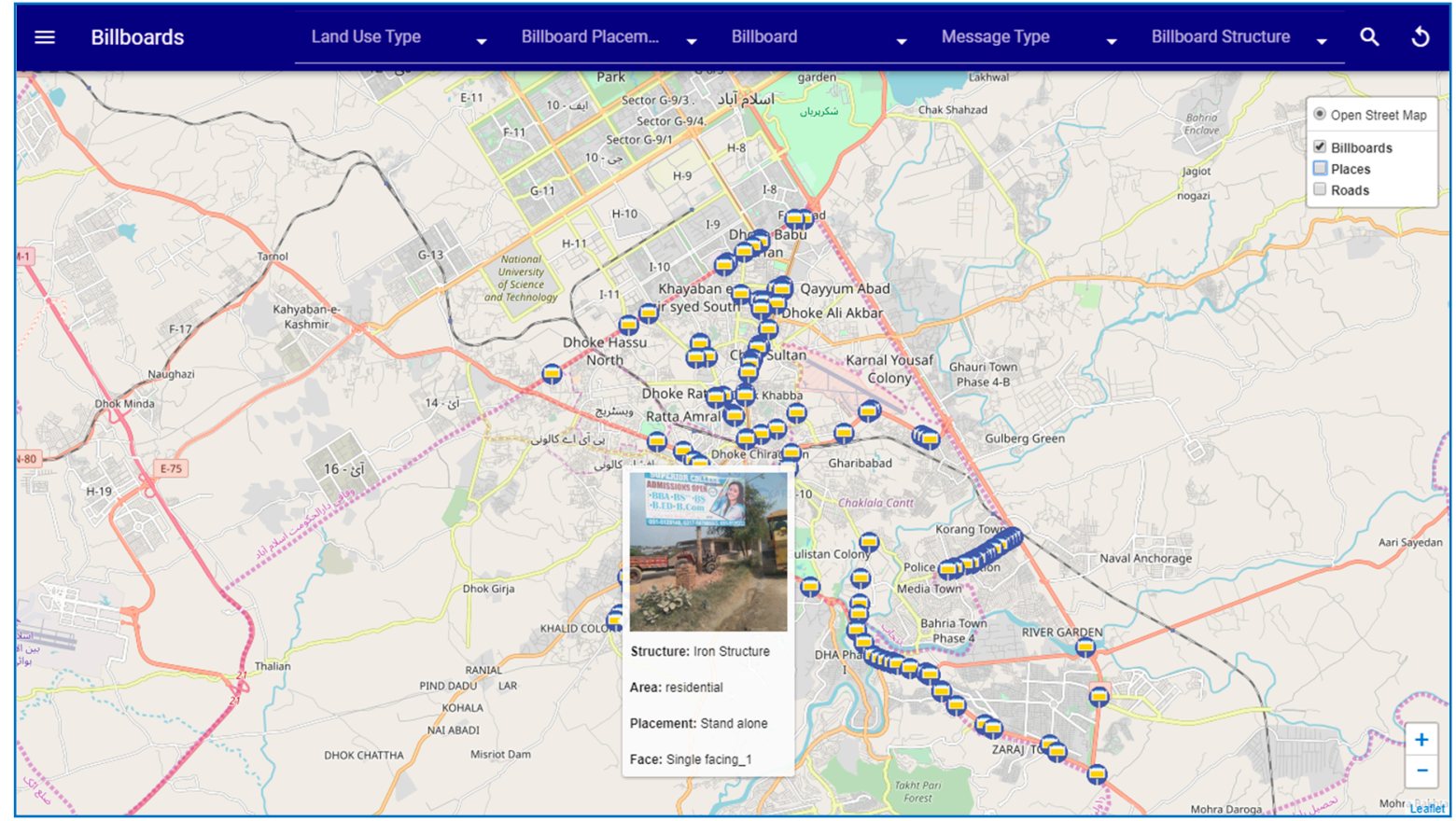

Figure 5. Basic system interface. 


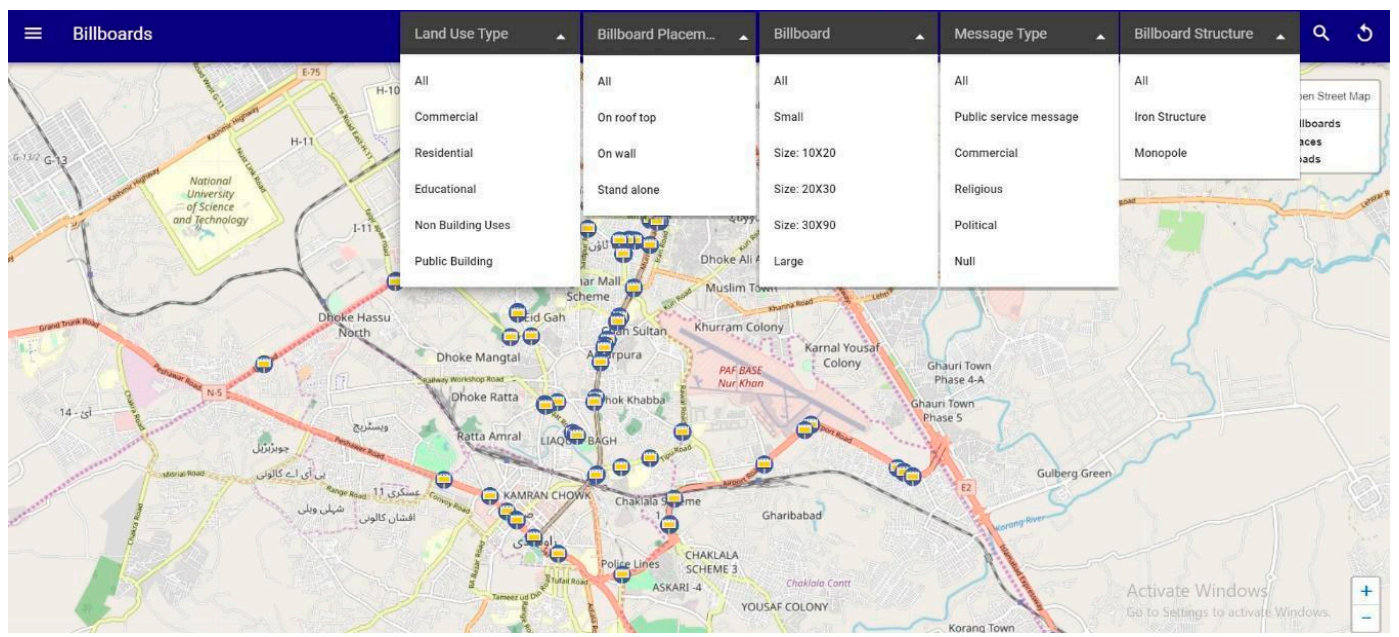

Figure 6. Attribute selection with filters.

Another GIS functionality, including buffer capability, is also added, which is the part of spatial queries performed on GIS dashboard. Buffers can be generated on billboards, roads and land parcels and the count of each billboard within that buffer range is displayed along with options of "buffer size", "buffer color" and "type of buffer"(i.e., along the road, billboard or parcel).

The SDSS offers user-category-specific functions to the advertisers and controlling agencies in addition to the general query functions. For instance, if a user is logged in as an advertiser, he/she can choose from two broad methods of site selection; a) multilayer query selection or b) fuzzy AHP. In the case of AHP, the user can pick from the site characteristics which may be used for pairwise comparison. The characteristics of the billboard sites include size, gross ratings points (GRP), eyes on impressions (EOI), daily estimated circulations (DEC), the demography of the neighborhood, the dominant land use of the adjacent site, the traffic flow in peak hours and the adjacent road type. Based on the user selection, a comparison matrix is generated on the fly, which allows the user to compare and rank choices on a scale of 1-9. The user is asked to record their preferences among all the selected site characteristics, and the system computes the values among the shortlisted sites from the higher-level area of interest (see Figure 7).

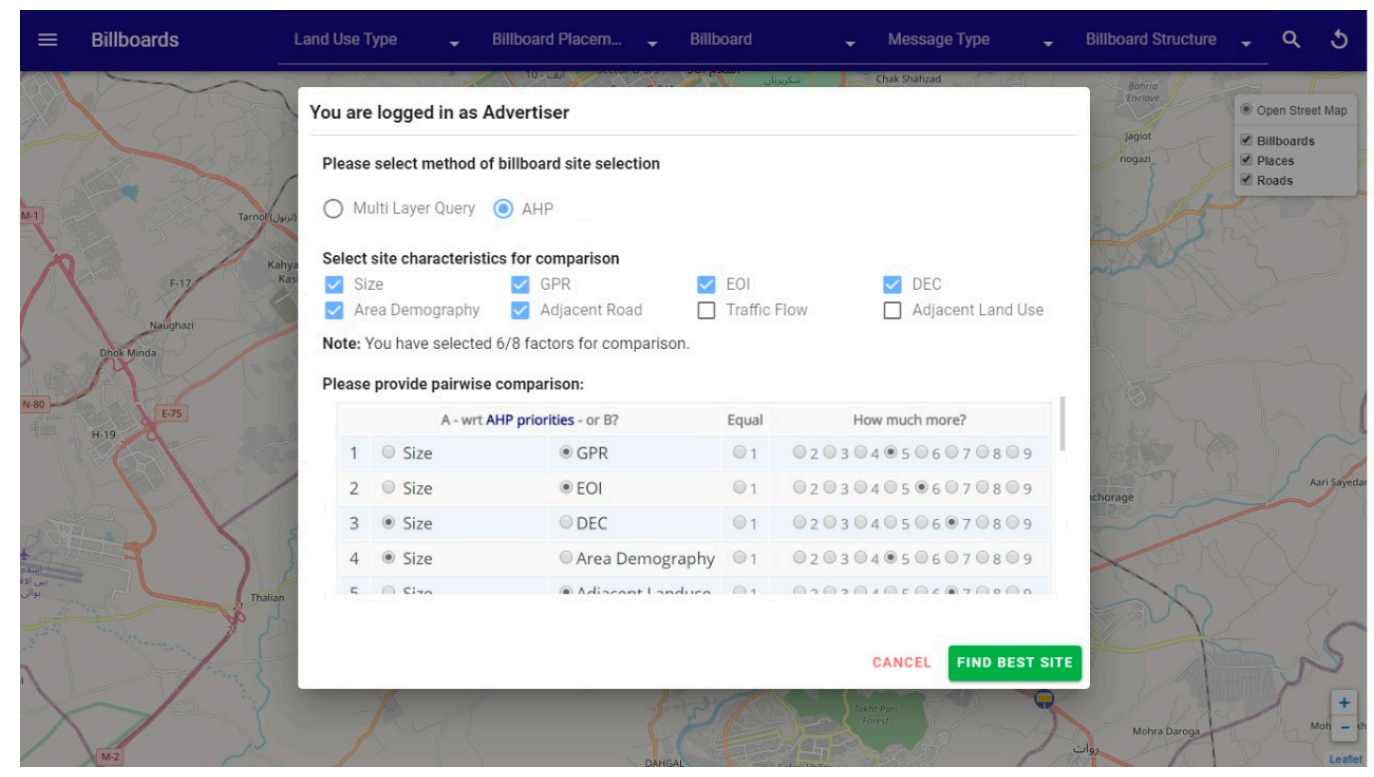

Figure 7. System interface allowing a user (advertisers) to choose criteria and specify pairwise comparison for fuzzy AHP calculation. 
In the case of a controlling agency, a different interface is presented to the user that matches their management functions. In this user case, AHP is particularly useful for exploring new potential sites to open for billboard installation. At the same time, routine management is mainly fulfilled by a multilayered query function. Figure 8 presents the screenshot where the user is allowed to use a graphical user interface to define criteria related to size, placement, condition, adjacency, site status, taxation and linear density.

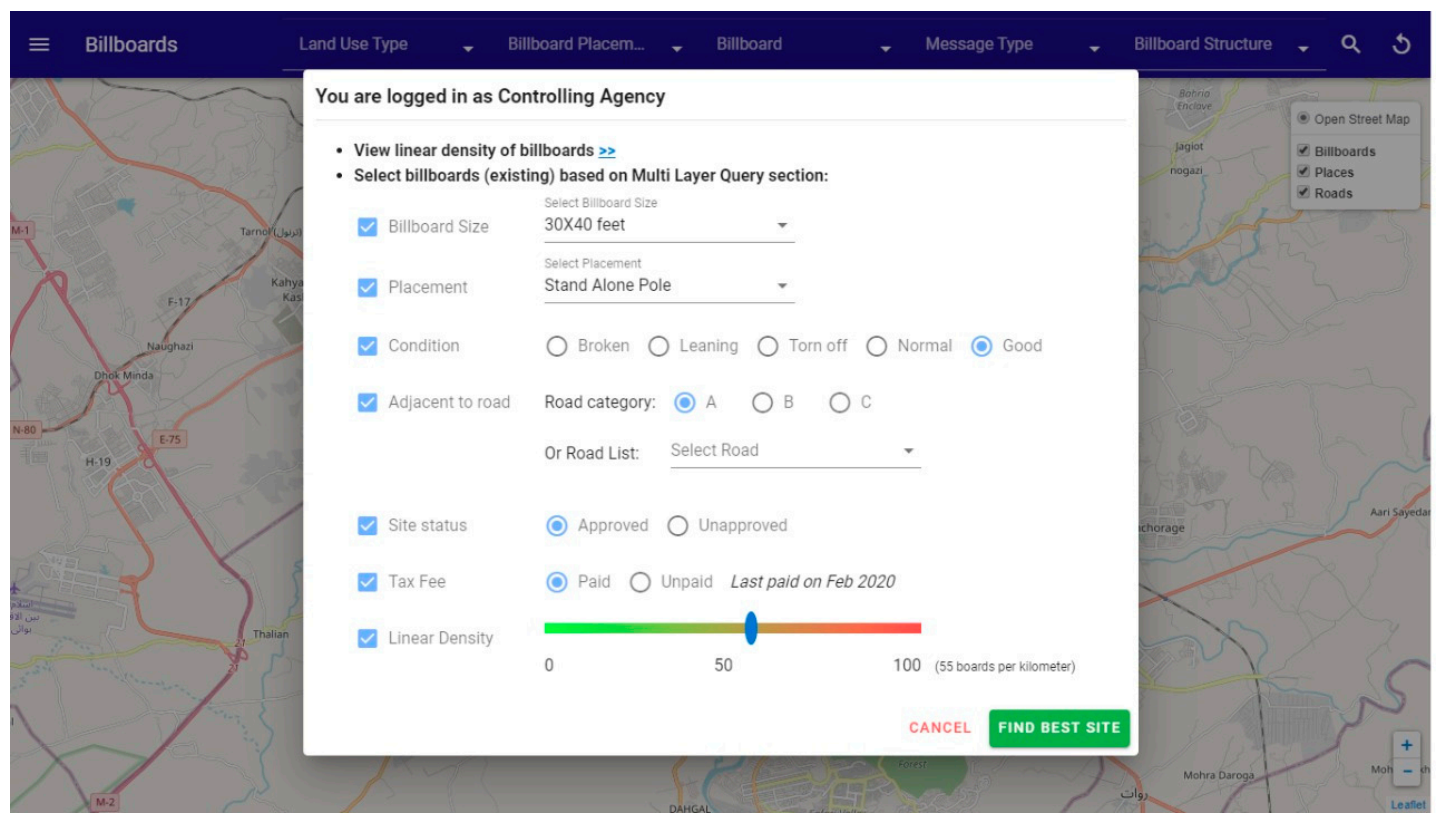

Figure 8. System interface allows a user (controlling agency) to select billboards based on multilayer query selection.

The initial feedback on the SDSS has been quite positive where the panellist has appreciated the SDSS with the strong hope that it will provide a practical solution to mitigate urban visual pollution. The government can use the tool for policy measures. The advertisers expressed higher satisfaction about the user interface and ease of site selection based on billboard characteristics and factors like GRP, EOI, DEC, demography and traffic. However, the need for 'more frequent data' or 'real-time data' on traffic arrived as a strong point for future updates.

\section{Conclusions}

Outdoor advertisements and billboards are a significant contributor to urban visual pollution. In many underdeveloped economies, a complete ban on billboards is not an available management option. The management of billboards in core urban centres is complex as it deals with competing requirements from different interest groups. On the development controlling agencies' side, billboards are a source of visual pollution, and their locational placement requires considering legal, marketing and ethical considerations. On the other hand, advertisers have a different set of considerations, as they need their advertisements to reach relevant community groups in targeted numbers for revenue generation. This research presents a web-based spatial decision support system to balance the stakeholders' competing requirements and offers them the ability to compare and contrast various indicators' compositions to attain the most suitable decision. In addition to the generic selection tools, the system allows for user-specific criteria input for either multilayered query selection or fuzzy AHP. In the case of controlling agencies, they can use the SDSS to identify potential sites to offer for billboard installation.

On the other hand, advertisers may select, compare and rank a series of indicators through a pairwise comparison approach resulting in the precise selection of suitable sites for any advertiser. The system uses open source development tools to create a friendly user 
interface that allows users to rate, select, and choose decision-making criteria. This research implements an AHP-inspired approach with on-the-fly calculations in web environment resulting in a more comprehensive output. The developed system has been presented to the elected officials of the development authorities employing a hands-on workshop. The users' initial feedback is highly encouraging as they find the system useful in achieving effective regulatory implementation and hotspot identification for the removal/ control of billboard placement to enhance visual aesthetics in urban areas.

Furthermore, it helps advertisers taking informed decisions in choosing the right locations for the placement of the right messages to the targeted communities. They feel better control in exploring options, which may offer them optimum output by considering traffic flow, community socio-economic background, billboard type, direction and size. In a nutshell, it helps to attain a win-win situation between advertisers and controlling authorities and eventually benefits urban areas' residents, who enjoy the better visual feel. For replicating this system in other developing countries, the knowledge modules should be tailored as per the local context. In terms of its technical implementation, the SDSS uses AHP and fuzzy AHP approaches in spatial decision-making. In comparison to the previous works $[17,172-175]$, this SDSS offers a more holistic solution to a broader spectrum of diverse stakeholder requirements. It is perceived that the system can be applied in other parts of developing world sharing the same characteristics as of the chosen case study in the research, particularly in developing countries facing the similar challenges of billboardization [170], institutional capacity, economy vs. aesthetic, and implementation loopholes.

Author Contributions: Conceptualization: Khydija Wakil, Muhammad Qadeer ul Hussnain, Ali Tahir; methodology, Khydija Wakil, Abdul Waheed, Muhammad Qadeer ul Hussnain, Ali Tahir; software, Khydija Wakil, Muhammad Qadeer ul Hussnain, Ali Tahir; formal analysis, Khydija Wakil, Muhammad Qadeer ul Hussnain; investigation, Khydija Wakil, Muhammad Qadeer ul Hussnain, Ali Tahir; resources, Abdul Waheed; Ali Tahir; data curation: Khydija Wakil, Muhammad Qadeer ul Hussnain; writing—original draft preparation, Khydija Wakil, Muhammad Qadeer ul Hussnain, Ali Tahir; writing - review and editing: Ali Tahir, Raheel Nawaz; visualization: Muhammad Qadeer ul Hussnain, Ali Tahir; supervision: Abdul Waheed; Ali Tahir, Raheel Nawaz; project administration: Abdul Waheed; Ali Tahir; funding acquisition: Abdul Waheed; Ali Tahir. All authors have read and agreed to the published version of the manuscript.

Funding: This research was funded by the Higher Education Commission (HEC), Pakistan, grant no: NRPU-6009 and the APC was funded by the National Universty of Sciences and Technology (NUST), Pakistan. The authors gratefully acknowledge their support.

Institutional Review Board Statement: Not applicable.

Informed Consent Statement: Informed consent was obtained from all subjects involved in the study.

Data Availability Statement: The data presented in this study are available on request from the corresponding author. The data are not publicly available due to the project completion requirements of the funding agency.

Acknowledgments: We acknowledge the anonymous reviewers' contributions in guiding us to clarify the concept and improvise the paper, especially the concept of "AHP-inspired approach", which was shared by a respectable reviewer. We thank Jamal Thaheem (Senior Lecturer, Construction Management, Deakin University, Australia) for his extensive contributions to improve the manuscript's linguistics.

Conflicts of Interest: The authors declare no conflict of interest.

\section{References}

1. Portella, A. Visual Pollution: Advertising, Signage and Environmental Quality; Routledge: Abingdon-on-Thames, UK, 2016.

2. Voronych, Y. Visual Pollution of Urban Space in LVIV. Master's Thesis, Politechnika Lwowska, Lviv Oblast, Ukraine, 2013; pp. 309-314.

3. Kadir, J.J. Deformation and visual pollution in the commercial streets of the old city of Mosul. Eurasian J. Sci. Eng. 2017. Available online: https: / / core.ac.uk/download/pdf/227204443.pdf (accessed on 29 January 2021). 
4. Allahyari, H.; Salehi, E.; Zebardast, L. Evaluation of visual pollution in urban squares, using SWOT, AHP, and QSPM techniques (Case study: Tehran squares of Enghelab and Vanak). Pollution 2017, 3, 655-667. [CrossRef]

5. Wakil, K.; Naeem, M.A.; Anjum, G.A.; Waheed, A.; Thaheem, M.J.; Hussnain, M.Q.U.; Nawaz, R. A Hybrid Tool for Visual Pollution Assessment in Urban Environments. Sustainability 2019, 11, 2211. [CrossRef]

6. Sivaramanan, S. Visual Pollution; Central Environmental Authority: Sri Jayawardenepura Kotte, Sri Lanka, 2016.

7. Wakil, K.; Naeem, M.A.; Anjum, G.A.; Waheed, A.; Thaheem, M.J.; Hussnain, M.Q. The assessment and mapping of urban visual pollution through an assembly of open source geospatial tools. In Proceedings of the Real Corp 2019 Proceedings, Karlsruhe, Germany, 2-4 April 2019; Volume 4, pp. 723-730.

8. McMahon, E. Litter on a Stick. Plan. Comm. J. 1998, 45, 123.

9. Bendak, S. The role of roadside advertising signs in distracting drivers. Int. J. Ind. Ergon. 2010, 40, 231-236. [CrossRef]

10. Dukic, T.; Ahlstrom, C.; Patten, C.; Kettwich, C.; Kircher, K. Effects of Electronic Billboards on Driver Distraction. Traffic Inj. Prev. 2013, 14, 469-476. [CrossRef] [PubMed]

11. Edquist, J. The Effects of Visual Clutter on Driving Performance; Monash University: Melbourn, Australia, 2009 ; p. 226.

12. Chmielewski, S.; Samulowska, M.; Lupa, M.; Lee, D.; Zagajewski, B. Citizen science and WebGIS for outdoor advertisement visual pollution assessment. Comput. Environ. Urban Syst. 2018, 67, 97-109. [CrossRef]

13. Płuciennik, M.; Sylla, M.; Gonda-Soroczyńska, E. The role of outdoor advertisements in the landscape of a city-public and private interests. Landsc. Archit. 2017, 55, 34-47.

14. Bankole, O.E. Urban Environmental Graphics: Impact, Problems and Visual Pollution of Signs and Billboards in Nigerian Cities. Int. J. Educ. Res. 2013, 1, 1-12.

15. Portella, A. Evaluating Commercial Signs in Historic Streetscape; Chapter 1-5; Oxford Brookes University: Oxford, UK, 2007.

16. Azeema, N.; Nazuk, A. Is Billboard a Visual Pollution In Pakistan? Int. J. Sci. Eng. Res. 2016, 7, 862-874.

17. Wakil, K.; Hussnain, M.Q.; Naeem, A.M.; Tahir, A. Regulating outdoor advertisement boards; employing spatial decision support system to control urban visual pollution. IOP Conf. Ser. Earth Environ. Sci. 2016, 37, 012060. [CrossRef]

18. Taylor, C.R.; Franke, G.R.; Bang, H.K. Use and effectiveness of billboards perspectives from selective-perception theory and retail-gravity models. J. Advert. 2006, 35, 21-34. [CrossRef]

19. Taylor, C.R.; Franke, G.R. Business perceptions of the role of billboards in the US economy. J. Advert. Res. 2003, 43, 150-161. [CrossRef]

20. Da Silva, M. Making Sense of Visual Pollution: The 'Clean City' Law in São Paulo, Brazil. In Toxic Truths; Manchester University Press: Manchester, UK, 2020; Available online: https:/ /library.oapen.org/bitstream/handle/20.500.12657/42642/9781526137005 fullhl.pdf?sequence=1\#page=173 (accessed on 29 January 2021).

21. Military Lands and Cantonments. Military Lands and Cantt Hoarding Policy; Military Lands and Cantonments: Karachi, Pakistan, 2012. Available online: http:/ / www.scribd.com/doc/211203418/Military-Lands-and-Cantt-Hoarding-Policy-2012 (accessed on 9 December 2015).

22. The City Government, Advertisement, Signage By-Laws Karachi; The City Government Laws: Karachi, Pakistan, 2003. Available online: http:/ / www.scribd.com/doc/211212901/The-City-Govt-Laws-on-Billboards-in-English-Highlights (accessed on 9 December 2015).

23. City District Government, City District Government Faisalabad Advertisement Byelaws. 2013. Available online: http://pcgip. urbanunit.gov.pk/docs/FinalAdvertisementByelaws2013Faisalabad[MEHRAN]withouttc.pdf (accessed on 12 December 2015).

24. PHUDD. Punjab Outdoor Advertisements and Sign Boards Policy; Government of Punjab: Lahore, Pakistan, 2008.

25. Hussnain, M.Q.; Anjum, G.A.; Wakil, K.; Tharanga, P.H.T.D. Improving Efficiency in Data Collection for Urban Development Plans through Information and Communication Technology; University of Engineering and Technology: Lahore, Pakistan, 2014.

26. Hasnain, K. Regulations on Outdoor Advertising. Dawn, 7 March 2013.

27. Maclurcan, D.C.B. Visual Pollution. Aust. Surv. 1973, 25, 82-88. [CrossRef]

28. Holdstein, R.E. The Problem of Visual Pollution and Its Relation to the Role of the Art Educator; Ohio State University: Columbus, OH, USA, 1974.

29. Bakhotmah, F.A. Visual Amenity E Visual Pollution Definition; Mass: Colombo, Sri Lanka, 1998.

30. Özyurt, M.; Kumbur, H. Visual Pollution in Mersin and its Environmental Effects. In Proceedings of the 12th International Symposium on Environmental Pollution and its Impact on Life in the Mediterranean Region, Antalya, Turkey, 4-8 October 2003.

31. Dunn, M. Educating for a Sustainable Community. Environmental Topic: Visual Pollution; The City of Albuquerque: Albuquerque, NM, USA, 2006.

32. Kratz, J.; Littlejohn, G. Visual Pollution. Green Teacher. 2007. Available online: http:/ / search.proquest.com/openview /8b3bda9 ffc55ef617035201aab10a998/1.pdf?pq-origsite=gscholar\&cbl=33544 (accessed on 30 January 2021).

33. Stapleton, R.M. Pollution A to Z. 2004. Available online: http:/ /www.pollutionissues.com/Ve-Z/Visual-Pollution.html (accessed on 30 January 2021).

34. Marinescu, D.; Truşcā, P. Visual Pollution and Aesthetic Education. Metalurgia 2010, 62, 41-45. Available online: http: / / search.ebscohost.com/login.aspx?direct=true\&profile=ehost\&scope=site\&authtype $=$ crawler $\&$ jrnl $=04619579 \& a s a=$ Y\&AN=48618211\&h=UDGsQ9it0BGCvBM\%2FqnPyNZrMh\%2BWBMrpJHd2dbgRreCHax0\%2FJGxTa0\%2BgsNsmcy\%2B9 UGybzhXCJAoN4KEm\%2BBlhn2A\%3D\%3D\&crl=c (accessed on 30 January 2021).

35. Meunier, S. Visual Pollution; Steidl: Göttingen, Germany, 2010. 
36. Portella, M.O. Environment and urban landscape: Advertising and outdoor advertising and visual pollution. Revista Direito Ambiental e Sociedade 2013. Available online: https:/ / www.researchgate.net/publication/287407937_Visual_pollution_Advertising_ signage_and_environmental_quality (accessed on 30 January 2021).

37. Beer, C. Adriana Portella: Visual Pollution: Advertising, Signage and Environmental Quality. Hum. Ecol. 2016, 44, 129-130. Available online: http:/ / search.proquest.com/openview /3951d14c52b0aa6de72c21440f46f311/1?pq-origsite=gscholar\&cbl=48 275 (accessed on 30 January 2021). [CrossRef]

38. Enache, E.; Morozan, C.; Purice, S. Visual Pollution: A New Axiological Dimension Of Marketing? Ann. Univ. Oradea Econ. Sci. Ser. 2012, 21, 820-826. Available online: http:/ / search.ebscohost.com/login.aspx?direct=true\&profile=ehost\&scope=site\& authtype $=$ crawler\&jrnl $=15825450 \& a s a=Y \& A N=85949029 \& h=x X L Z R Q m l k X P D z j e u z v o S b 9 n T h p n t H N 0 h P T Y z n J k P 5 P 83 S 6 j 76 f 0$ 964al4\%2Fjm\%2FC5\%2FuY8\%2B3I83x5jP668pcGJzjA\%3D\%3D\&crl=c (accessed on 30 January 2021).

39. Jacksonville Community Council, Inc. Visual Pollution Study. 1985. Available online: https://digitalcommons.unf.edu/jcci/4 (accessed on 30 January 2021).

40. Barrett, J.H. Visual Pollution in a national park. Mar. Pollut. Bull. 1972, 3, 25-27. Available online: https:/ / www.sciencedirect. com/science/article/pii/0025326X72902147 (accessed on 30 January 2021). [CrossRef]

41. Troy, L. Visual Pollution in WA; Claremont Teachers College: Perth, Australia, 1974.

42. Flad, H.K. Country clutter: Visual pollution and the rural roadscape. Ann. Am. Acad. Pol. Soc. Sci. 1997, 553, 117-129. [CrossRef]

43. Muthukrishnan, N. Visual Pollution-More Dangerous than You Think It Is. CPR Environmental Education System. 2015. Available online: http:/ / cpreec.org/161.htm (accessed on 5 March 2019).

44. Cheng-lin, H. On the Problems of Touring Ecology Destruction and Visual Pollution in the "Two-Mountain and One-Lake Area" of Anhui Province. J. Catastrophol. 2003. Available online: http:/ / en.cnki.com.cn/Article_en/CJFDTotal-ZHXU200304015.htm (accessed on 30 January 2021).

45. Xin, S.U.N. Discussion of Visual Pollution in City. China Environ. Manag. 2011. Available online: http://en.cnki.com.cn/Article_ en/CJFDTotal-HJGN201104019.htm (accessed on 30 January 2021).

46. Elena, E.; Cristian, M.; Suzana, P. Visual Pollution: A New Axiological Dimension of Marketing? Ann. Fac. Econ. 2012, 1, 820-826.

47. Al Zaydee, N.M. Visual pollution in the city of Mosul (A study in geographic contamination). Mosoliya Stud. 2013. Available online: https: / / www.iasj.net/iasj?func=article\&aId=76673 (accessed on 30 January 2021).

48. Anciaes, P.R. Book Review: Visual Pollution: Advertising, Signage and Environmental Quality by Adriana Portella; LSE Review of Books: London, UK, 2014; Available online: http:/ / eprints.lse.ac.uk/57500/ (accessed on 30 January 2021).

49. Grygny, N. Reklama w Przestrzeni Miejskiej Visual Pollution-Zawłaszczanie i Odzyskiwanie Miasta. Ph.D. Thesis, Zachodniopomorski Uniwersytet Technologiczny, Szczecin, Poland, 2014.

50. Codato, M.V.F. Visual pollution and noise: A troubled relationship between environment and society. Rev. Eletrônica Gestão Educ. Tecnol. Ambient. 2014. Available online: https://periodicos.ufsm.br/index.php/reget/article/view/14516 (accessed on 30 January 2021).

51. Jana, M.K.; De, T. Visual pollution can have a deep degrading effect on urban and suburban community: A study in few places of Bengal, India, with special reference to unorganized billboards. Eur. Sci. J. 2015, 7881, 1-14.

52. Babcock, H. Is using the public trust doctrine to protect public parkland from visual pollution justifiable doctrinal creep. Ecol. $L Q$ 2015, 42, 1 .

53. Blewitt, J. Visual Pollution: Advertising, Signage and Environmental Quality; Taylor \& Francis: Oxfordshire, UK, 2015.

54. Somida, I.D.A. The Effect of Visual Pollution on Double Meaning of The Facad. Master's Thesis, Cairo University, Giza, Egypt, 2015.

55. Correa, V.F.; Mejía, A.A. Visual pollution Indicators and its Effects on Population. Enfoque UTE 2015. Available online: http: / / scielo.senescyt.gob.ec/scielo.php?script=sci_arttext\&pid=S1390-65422015000300115\&lng=en\&nrm=iso\&tlng=en (accessed on 30 January 2021).

56. Kharate, S.; Banerjee, S. A Study of Visual pollution and Its Effect on Mental Health. Innov. IT 2016, 3, 35-37. Available online: https: / / www.indianjournals.com/ijor.aspx?target=ijor:jiit\&volume=3\&issue=1\&article=008 (accessed on 30 January 2021).

57. Banerjee, S. A study of visual pollution and its effect on mental health. Sch. Res. J. Interdiscip. Res. 2017. Available online: https:// www.academia.edu/33171208/A_STUDY_OF_VISUAL_POLLUTION_AND_ITS_EFFECT_ON_MENTAL_HEALTH (accessed on 30 January 2021).

58. Tota, A.L. 'Poluição visual': Uma reflexão sobre a sustentabilidade de imagens "Visual pollution": A reflection on the sustainability of images. RBSE Rev. Bras. Sociol. Emoção 2017. Available online: http:/ / www.cchla.ufpb.br/rbse/RBSEv.16n.47ago2017completo. pdf\#page=105 (accessed on 30 January 2021).

59. EL-Ghonaimy, I.H. Visual pollution phenomena and sensitivity of residences in heritage city centers Case of: Old district of Manama city, Kingdom of Bahrain. J. Contemp. Urban Aff. 2019, 3, 175-190. Available online: http://www.ijcua.com/index.php/ ijcua/article/view/125 (accessed on 30 January 2021). [CrossRef]

60. Szczepańska, M.; Wilkaniec, A.; ŠkaMlová, A. Visual pollution in natural and landscape protected areas: Case studies from Poland and Slovakia. Quaest. Geogr. 2019, 38, 133-149. Available online: https://content.sciendo.com/view/journals/quageo/38 /4/article-p133.xml (accessed on 30 January 2021). [CrossRef] 
61. Kim, J.; Kim, Y. Visual pollution on public sites affecting public sights. In Proceedings of the 32th KKHTCNN Symposium on Civil Engineering, Daejeon, Korea, 24-26 October 2019; Available online: https:/ / koasas.kaist.ac.kr/handle/10203/276299 (accessed on 30 January 2021).

62. Campos, C.; Cirafici, A. Visual Pollution and Social Asymmetry. The Origin of Dientenegro. Disegnarecon 2020. Available online: http://disegnarecon.univaq.it/ojs/index.php/disegnarecon/article/view/731 (accessed on 30 January 2021).

63. Tama, B. Visual Pollution in the Urban Environment. 2020. Available online: https://nda.rtu.lv/en/view/25589 (accessed on 30 January 2021).

64. Cvetković, M.; Momčilović-Petronijević, A.; Ćurčić, A. Visual Pollution of Urban Areas as One of the Main Issues of the 21st Century. Available online: https://www.researchgate.net/profile/Mila_Cvetkovic3/publication/331718054_VISUAL_ POLLUTION_OF_URBAN_AREAS_AS_ONE_OF_THE_MAIN_ISSUES_OF_THE_21ST_CENTURY / links /5c8bca3da6fdcc3 81755c205/VISUAL-POLLUTION-OF-URBAN-AREAS-AS-ONE-OF-THE-MAIN-ISSUES-OF-THE-21ST-C (accessed on 30 January 2021).

65. Jorge, A.P.; Gentil, P.A.B. Social Da Propriedade: A Problemática Da Poluição Visual, Social Function Of Property: The Problem of Visual Pollution. 2009. Available online: https://www.jfrj.jus.br/sites/default/files/revista-sjrj/arquivo/7-23-1-pb.pdf (accessed on 30 January 2021).

66. Schodorf, R.J. A Study of Visual Pollution from Overhead Wires and Associated Structures. Master's Thesis, Western Michigan University, Kalamazoo, MI, USA, 1973.

67. Silverstone, S. Visual Pollution: Unaesthetic Use of Land as Nuisance. Alta. Law Rev. 1974, 12. Available online: http: //www.albertalawreview.com/index.php/ALR/article/view/2371 (accessed on 30 January 2021). [CrossRef]

68. Allen, M. The SAGE Encyclopedia of Communication Research Methods; SAGE Publications, Inc.: Thousand Oaks, CA, USA, 2017.

69. Fischer, L.; Abllez, M.E. Campus Communication or Visual Pollution? 1996. Available online: https://scholarworks.lib.csusb. edu/cgi/viewcontent.cgi?article=1396\&context=coyote-chronicle (accessed on 30 January 2021).

70. Zbadi, H. An Analytical Study of the Symptoms and Causes of Visual Pollution in the Contemporary Egyptian City. Master's Thesis, Department of Architecture, Assiut University, Assiut, Egypt, 1997.

71. Dumitrescu, A. Dams, visual pollution and environment damage. Rev. Ecol. Ind. 2000, 7, 59-62.

72. Dumitrescu, A. Wind turbines, solar panels and visual pollution. Rev. Ecol. Ind. 2000, 7, 63-66.

73. Nagle, J.C. Cell phone towers as visual pollution. Notre Dame JL Ethics Pub. Pol'y 2009, 23, 537.

74. Marks, P. Projector phones: Cool app or visual pollution. New Sci. 2009, 201, 18-19. Available online: https://www.sciencedirect. com/science/article/pii/S0262407909605650 (accessed on 30 January 2021). [CrossRef]

75. Sumartono, S. Visual Pollution in the Context of Conflicting Design Requirements. J. Vis. Art Des. 2009. Available online: http://journals.itb.ac.id/index.php/jvad/article/view/742 (accessed on 30 January 2021). [CrossRef]

76. Roca, M.A.S. Visual pollution by television antennas on the Albaicin. A technologic proposal for its correction. $e$-Rph-Rev. Electron. Patrim. Hist. 2011, 59-88. Available online: https://dialnet.unirioja.es/servlet/articulo?codigo=5370842 (accessed on 30 January 2021).

77. Jensen, C.U.; Panduro, T.E.; Lundhede, T.H. The vindication of Don Quixote: The impact of noise and visual pollution from wind turbines. Land Econ. 2014, 90, 668-682. [CrossRef]

78. Ogunbodede, R.S.E.F. Posters, Banners and Billboards Visual Pollution in Nigerian Urban Environment: Challenges to Urban Managers. IOSR J. Humanit. Soc. Sci. 2014, 19, 56-64. [CrossRef]

79. Azeema, N. Billboard Advertisement Visual Pollution; Dr. Bernard Weitzman: New York, NY, USA, 2015.

80. Madleňák, R.; Hudák, M. The Research of visual pollution of road infrastructure in Slovakia. In International Conference on Transport Systems Telematics; Springer: Cham, Switzerlands, 2016; Available online: https://link.springer.com/chapter/10.1007/ 978-3-319-49646-7_35 (accessed on 30 January 2021).

81. Nami, P.; Jahanbakhsh, P.; Fathalipour, A. The Role and Heterogeneity of Visual Pollution on the Quality of Urban Landscape Using GIS; Case Study: Historical Garden in City of Maraqeh. Earth Env. Sci. 2016, 6, 20-29. [CrossRef]

82. Probst, A.K. Environmental Visual Pollution and Its Relationship to Signage Technology: A Case Study in Thailand. Master's Thesis, University of Cincinnati, Cincinnati, OH, USA, 2016.

83. Naguib, M.M. Visual pollution caused by banners and signage installed on buildings facades Case study: Alexandria versus Moscow city. Int. J. Sci. Eng. Res. 2016, 7, 1663-1667.

84. Khanal, K.K. Visual pollution and eco-dystopia: A study of billboards and signs in Bharatpur metropolitan city. Res. J. Engl. Lang. Lit. 2018, 6, 202-208. Available online: http:/ / rjelal.com/6.1.18/202-208KAMALKRISHNAKHANAL.pdf (accessed on 30 January 2021).

85. Urban, M.; Avilés, D.J.V.; Bojović, M.; Urban, K. Artificial, cheap, fake: Free associations as a research method for outdoor billboard advertising and visual pollution. Hum. Aff. 2020, 30, 253-268. Available online: https://www.degruyter.com/view/ journals / humaff/30/2/article-p253.xml (accessed on 30 January 2021). [CrossRef]

86. Wakil, K.; Hussnain, M.Q.; Waheed, A.; Naeem, A.M. Contextual Review of Outdoor Advertisements: Impacts and Regulatory Practices. Sci. Int. 2016, 1, 531-535.

87. McEvoy, J.; Williams, S. Visual Pollution in the Lake Tahoe Basin: A Report to the Tahoe Regional Planning Agency Based on the Application of a Quantitative Method of Assessing the Visual Environment; University of California: Oakland, CA, USA, 1976.

88. Williams, J.M.S., III. Visual Pollution in the Lake Tahoe Basin; University of California: Davis, CA, USA, 1970. 
89. Xiu, S.; Zhou, Q.; Cai, Q.; Long, L.; Lu, D.; Shang, X. Investigation and Research of University Campus Visual Pollution. Bull. Sci. 2009. Available online: http://en.cnki.com.cn/Article_en/CJFDTotal-KJTB200903024.htm (accessed on 30 January 2021).

90. Yilmaz, D.; Sagsöz, A. In the context of visual pollution: Effects to trabzon city center silhoutte. Asian Soc. Sci. 2011. [CrossRef]

91. Emeji, M.J. Environmental Communication and Visual Pollution in the Nigerian City of Port Harcourt: Implications for Design Education and City Planning. Vis. Arts Res. 2011, 37, 42-53. Available online: https://muse.jhu.edu/article/451821/summary (accessed on 30 January 2021). [CrossRef]

92. Mousa, I. Visual Pollution in the Commercial Streets in Duhok City; Higher Institute of Urban Planning, the University of Duhok: Dahuk, Iraq, 2011; Available online: https:/ / www.researchgate.net/publication/342851846_REPERCUSSION_OF_VISUAL_ POLLUTION_AND_ITS_EFFECTS_ON_SOME_PEOPLE_IN_DUHOK (accessed on 30 January 2021).

93. Mendez, V.; Carmen, A. Visual pollution in public spaces in Venezuela. Gestión Ambient. 2013, 16, 45-60. Available online: https:/ /inis.iaea.org/search/search.aspx?orig_q=RN:45026928 (accessed on 30 January 2021).

94. Kan, R.; Ngai, S.; Wong, C.Y. Visual Pollution in Hong Kong. 2012. Available online: http://hku-env-health.blogspot.in/2012/1 1/visual-pollution-in-hong-kong-byr-kan.html (accessed on 10 May 2014).

95. Sabah, O.A.; Samad, M.H. Livable Heritage Street and Visual Pollution In Georgetown/Penang. Int. Conf. Liveable Cities 2015. Available online: http://www.academia.edu/download/46329828/LIVABLE_HERITAGE_STREET_AND_VISUAL_ POLLUTION_IN_GEORGETOWN-PENANG.pdf (accessed on 30 January 2021).

96. Benavides, D.A.M. Environmental Diagnosis of Visual Pollution Perception by University Population from the Civil Engineering and Natural, Exact and Education Sciences Faculties at Universidad del Cauca. Luna Azul 2017, 44, 211-230. Available online: http: / / www.scielo.org.co/scielo.php?pid=S1909-24742017000100013\&script=sci_arttext\&tlng=en (accessed on 30 January 2021). [CrossRef]

97. Cvetković, M.; Momčilović-Petronijević, A. Visual Pollution of the Historical City Core-A Case Study, the City of Niš. In Proceedings of the 6th International Conference Contemporary Achievements in Civil Engineering, Subotica, Serbia, 20 April 2018; Available online: http:/ / zbornik.gf.uns.ac.rs/doc/NS2018.49.pdf (accessed on 30 January 2021).

98. Anwer, M.; Aowais, A. Visual Pollution and its Impact on the Aesthetics: The Town of Eizariya as a Model. J. Plan. Dev. 2019, 24, 44-70. Available online: https:/ /www.iasj.net/iasj/article/184101 (accessed on 30 January 2021).

99. Zaeimdar, M.; Sarab, F.K.; Rafati, M. Investigation of the relation between visual pollution and citizenry health in the city of Tehran (case study: Municipality districts No. 1 \& 12 of Tehran). Anthropog. Pollut. 2019, 3, 1-10. Available online: http:/ / ap.iauardabil.ac.ir/article_546040.html (accessed on 30 January 2021).

100. Córdoba, L.Y. The Historical Environment of the City of Cartagena Opaque by Commercial Visual Pollution. Aglala 2013, 4, 72-92. Available online: https:/ / revistas.curn.edu.co/index.php/aglala/article/view/733 (accessed on 30 January 2021).

101. Erickson, L.E. Approach to Valuing Visual Pollution from Western Electricity Production; Battelle Pacific Northwest Labs: Richland, WA, USA, 1977. Available online: https:/ / www.osti.gov/biblio/7307006 (accessed on 30 January 2021).

102. Jellet, P. Beachwatch Visual Pollution Ratings 1 July 1991 to 31 March 1993: Data Analysis and Modelling; NSW Environment Protection Authority (EPA): Parramatta, Australia, 1993.

103. Khaled, M.T.J. Analyzing and Evaluating Visual Pollution in Tulkarem City (Center of Tulkarem City-Case Study). 2009. Available online: https:/ / repository.najah.edu/handle/20.500.11888/7484 (accessed on 27 January 2021).

104. Zhou, D.; Wang, B.J.; Shi, B. GIS Viewshed Analysis of Visual Pollution Assessment for Mine Environment. Xuebao J. Guilin Univ. 2011. Available online: http:/ / en.cnki.com.cn/Article_en/CJFDTotal-GLGX201102009.htm (accessed on 30 January 2021).

105. Gokhale, I.R.V.A.; Raichur, M. Examining Impact of Visual Pollution on City Environment: Case Study of Pune, India. Available online: https://www.academia.edu/17307236/Examining_Impact_of_Visual_Pollution_on_City_Environment_Case_Study_ of_Pune_India (accessed on 27 January 2021).

106. Luo, X.; Huang, Y. The Analyses of Visual Pollution Problem and Its Strategies in Historic District. Mod. Urban Res. 2011. Available online: http:/ / en.cnki.com.cn/Article_en/CJFDTotal-XDCS201103015.htm (accessed on 30 January 2021).

107. Atta, H.A. Visual pollution and statistical determination in some of Karrada district main streets, Baghdad. J. Eng. 2013, 19, 414-428.

108. Souad, B.F. The Impact of Visual Pollution on Historic Buildings (Tlemcen City, Algeria: Model). Shedet 2014, 1, 35-50. Available online: https:/ / shedet.journals.ekb.eg/article_87632.html (accessed on 30 January 2021).

109. Kamičaitytė-Virbašienè, J.; Godienè, G.; Kavoliūnas, G. Methodology of Visual Pollution Assessment for Natural Landscapes. J. Sustain. Archit. Civ. Eng. 2016, 13. [CrossRef]

110. Kamičaitytè-Virbašienè, J.; Godienè, G. Analysis of Legal and Theoretical Framework Creating the Methodology of Visual Pollution Assessment for Natural Landscapes. J. Sustain. 2015, 44-56. Available online: https:/ / www.ceeol.com/search/articledetail?id=483560 (accessed on 30 January 2021).

111. Lascu, L.F. The Impact of Visual Pollution on Quality of Life. Case Study: The Historic Core of Bucharest. Calitatea 2015, 16, 662-666. Available online: http://search.proquest.com/openview /5831355d3b0b410d59c511413801b8cd/1?pq-origsite= gscholar\&cbl=1046413 (accessed on 30 January 2021).

112. Chmielewski, S.; Lee, D.J.; Tompalski, P.; Chmielewski, T.J.; Wężyk, P. Measuring visual pollution by outdoor advertisements in an urban street using intervisibilty analysis and public surveys. Int. J. Geogr. Inf. Sci. 2016, 30, 801-818. [CrossRef] 
113. Al-Sharaa, A.; Bakar, S.A.; Maulan, S.B. Determining Peoples Threshold Towardes Visual Pollution Using Areal Comulative Analysis and Public Survey. MLA Seminar 2016. Available online: http://mlaupm.com/an-component/media/download/ MLA_SEMINAR_2016.pdf\#page=18 (accessed on 30 January 2021).

114. Bakar, S.A.; al-Sharaa, A.; Maulan, S.; Munther, R. Measuring Visual Pollution Threshold along Kuala Lumpur Historic Shopping District Streets Using Cumulative Area Analysis; SUNY College of Environmental Science and Forestry: Syracuse, NY, USA, 2019; Available online: https:/ / digitalcommons.esf.edu/vrconference/16/ (accessed on 30 January 2021).

115. Roca, M.A.S. Numerical assessment of visual pollution degree in an "cultural interest good": Methodology for implementation. Application of this method to the Albaicin neighbourhood of Granada. E-RPH-Rev. Electron. Patrim. Hist. 2016, 18, 70-83.

116. Kucharikova, Z.; Simko, J. Visual pollution localization through crowdsourcing and visual similarity clustering. In Proceedings of the 2017 12th International Workshop on Semantic and Social Media Adaptation and Personalization (SMAP), Bratislava, Slovakia, 9-10 July 2017; Available online: https:/ / ieeexplore.ieee.org/abstract/document/8022662/ (accessed on 30 January 2021).

117. Shaban, L.K.; Suleiman, S.; Abdel-Aziz, D.; Isawi, H.Y. Evaluating the Visual Pollution in Urban Corridors-Case of Al-Madina Al-Munawara Corridor, Amman. Res. J. Appl. Sci. Eng. Technol. 2018, 15, 288-294. Available online: https://www.airitilibrary. com/Publication/alDetailedMesh?docid=20407467-201808-201811230017-201811230017-288-294 (accessed on 30 January 2021). [CrossRef]

118. Xiaolan, T.; Yanyan, J.; Wenyuan, B. An Analysis of Visual Pollution Problems and Countermeasures in the Construction of Beautiful Urban-Rural Areas. J. Nanjing For. 2018. Available online: http:/ / en.cnki.com.cn/Article_en/CJFDTotal-NJLS2018020 08.htm (accessed on 30 January 2021).

119. Melhosseini, D.K.; Mortazavi, S.; Hosseini, S.M.; Shayesteh, K.; Falahatkar, S. Investigating the Visual Pollution of NonHeterogeneous Land Uses in the Tourist Areas (Case Study: Dohezar And Sehezar Forests of Tonekabon). J. Appl. RS GIS Tech. Nat. Resour. Sci. 2018, 9, 47-58. Available online: https:/ / www.sid.ir/en/journal/ViewPaper.aspx?id=597316 (accessed on 30 January 2021).

120. Ahmed, N.; Islam, M.N.; Tuba, A.S.; Mahdy, M.R.C.; Sujauddin, M. Solving visual pollution with deep learning: A new nexus in environmental management. J. Environ. Manag. 2019, 248, 109253. Available online: https:/ / www.sciencedirect.com/science/ article/pii/S0301479719309557 (accessed on 30 January 2021). [CrossRef]

121. Al-Anbari, M.A.; Abd, M.A.; Obaid, A.H. Evaluation of Some Visual Pollution Indicators in the Physical Environment of Al-Hilla City. Muthanna J. Eng. Technol. 2020, 8, 10-25. Available online: http://engineering.uobabylon.edu.iq/fileshare/articles/ repository1_publication6158_15_227.pdf (accessed on 30 January 2021).

122. Radomska, M.; Yurkiv, M.; Nazarkov, T. The Assessment of the Visual Pollution from Industrial Facilities in Natural Landscapes. Available online: http:/ / www.kdu.edu.ua/EKB_jurnal/2019_1(27)/PDF/45_49.pdf (accessed on 30 January 2021).

123. Ramos, C.V.; Treviño, M.G.M. Perception of Visual Contamination of the Population of the City of H. Matamoros, Tamaulipas. Mexico. Available online: http://www.eumed.net/rev/cccss/2017/03/contaminacion-visual-mexico.zip (accessed on 30 January 2021).

124. Chmielewski, S. Chaos in Motion: Measuring Visual Pollution with Tangential View Landscape Metrics. Land 2020, 9, 515. [CrossRef]

125. Yellin, I.E. Visual Pollution and Aesthetic Regulation. Los Angeles Bar Bull. 1971, 11, 425-434, 456, 458.

126. Robinette, G. Plants for easing visual pollution, or ways to overcome ugliness [Beautification]. Yearbook of Agriculture U.S. Dept. of Agriculture. 1972. Available online: http://agris.fao.org/agris-search/search.do?recordID=US19790421803 (accessed on 30 January 2021).

127. Eyenga, I.I.; Focke, W.W.; Prinsloo, L.C.; Tolmay, A.T. Photodegradation: A solution for the shopping bag 'visual pollution' problem? Macromol. Symp. 2002, 178, 139-152. [CrossRef]

128. Furze, J. Stealth wind turbines: Designs and technologies to reduce visual pollution. Refocus 2002, 3, 18-20. Available online: https:/ / www.sciencedirect.com/science/article/pii/S1471084602800221 (accessed on 30 January 2021). [CrossRef]

129. Rescia, P.; Corbetta, E.; Puletti, M.; Rizzi, W.; Tornquist, J. Offshore Plants Visual Pollution Mitigation. In Proceedings of the SPE International Conference on Health, Safety, and Environment in Oil and Gas Exploration and Production, Calgary, AB, Canada, 29-31 March 2004; Available online: https:/ / www.onepetro.org/conference-paper/SPE-86778-MS (accessed on 30 January 2021).

130. Chuan, W. Stop Urban Visual Pollution. Archit. Cult. 2009. Available online: http://en.cnki.com.cn/Article_en/CJFDTotalJZYW200911020.htm (accessed on 30 January 2021).

131. Stephany, T.J. Energy Generation System for Reduced Visual Pollution and Cost. U.S. Patent Application 12/189,777, 11 February 2010. Available online: https:/ / patents.google.com/patent/US20100032957A1/en (accessed on 30 January 2021).

132. Bi-xuan, M. On exploration for management and strategies of visual pollution in historic streets. Shanxi Archit. 2014. Available online: http:/ / en.cnki.com.cn/Article_en/CJFDTotal-JZSX201416011.htm (accessed on 30 January 2021).

133. Bedin, B.; Ferrari, M.; Gajardo, R. Visual Pollution and Its Control in Caxias do sul County from the Municipal Law no. 412/2012/a Poluicao Visual e o seu Controle no Municipio de Caxias do sul a Partir da lei Municipal no. 412/2012. Direito da Cidade. 2015. Available online: https:/ / go.gale.com/ps/i.do?id=GALE\%7CA566559048\&sid=googleScholar\&v=2.1\&it=r\&linkaccess=abs\& issn=23177721 \&p=IFME\&sw $=\mathrm{w}$ (accessed on 30 January 2021).

134. Cercleux, A.-L.; Merciu, F.-C.; Merciu, G.-L. A Model of Development Strategy Encompassing Creative Industries to Reduce Visual Pollution-Case study: Strada Franceză, Bucharest's Old City. Procedia Environ. Sci. 2016, 32, 404-411. [CrossRef] 
135. Abdelhamid, M.M. An Attempt to Reduce Visual Pollution in the Building Sector within Egyptian Cities. Spaces Flows Int. J. Urban Extra Urban Stud. 2018, 9, 23-34. Available online: http:/ / search.ebscohost.com/login.aspx?direct=true\&profile=ehost\& scope $=$ site\&authtype $=$ crawler \&jrnl $=21548684 \& A N=136111844 \& \mathrm{~h}=\mathrm{M} 7 \mathrm{nkngiEkrFWaO} \% 2 \mathrm{FxF}$ 4Tq8SZZdZA1ZPxrhWTkF\% 2BSsKqwHeoj3OTeqRZgI6Z5zjivyVFPBQzHadV9s\%2Bt0460bpA\%3D\%3D\&crl=c (accessed on 30 January 2021). [CrossRef]

136. Nessim, A.A. Visual Pollution: An Approach to Reduce the Environmental Impact of Light Pollution in Egypt. In Architecture and Urbanism: A Smart Outlook; Springer: Cham, Switzerlands, 2020; Available online: https://link.springer.com/chapter/10.1007/97 8-3-030-52584-2_33 (accessed on 30 January 2021).

137. Choudhary, A.; Shrivastava, A.T. Model to mitigate visual polluution by Ads and signage. Int. J. Eng. Res. Gen. Sci. 2016, 4, 516-521.

138. Jian, A. Road Traffic Safety Management of Visual Pollution By Outdoor Advertisements. Master's Thesis, Universiti Teknologi Malaysia, Skudai, Malaysia, 2020.

139. Sahana, S.; Karthigayini, S. Design Strategies to Reduce the Impact of Visual and Noise Pollution in Urban Areas. Asian Rev. Environ. Earth Sci. 2020, 7, 67-71. Available online: https://core.ac.uk/download/pdf/327110692.pdf (accessed on 30 January 2021).

140. De Loyola, R.B. Berleant's Non-Cognitive Engagement Approach in Remedying the Problem on Urban Visual Pollution. Available online: https:/ / www.dlsu.edu.ph/wp-content/uploads/pdf/conferences/arts-congress-proceedings/2018/acp-02.pdf (accessed on 30 January 2021).

141. Wakil, K.; Hussnain, M.Q. Regulatory Mechanisms for Outdoor Advertisement Boards in Lahore. In Proceedings of the 2014 International Conference on Town Planning and Urban Management (ICTPUM 2014), Lahore, Pakistan, 29-30 September 2014; Available online: http:/ / citypulse.com.pk/publications/Regulatorymechanismforadvertisementboardsinlahore.pdf (accessed on 16 February 2019).

142. Club, S. Visual Pollution. Sierra Club Policies; Sierra Club: Oakland, CA, USA, 1966.

143. Sadeghi, R.; Mazloomy-Mahmoodabad, S.S.; Rezaeian, M.; Fallahzadeh, H.; Khanjani, N. The application of geographic information systems (ArcGIS) in selecting locations for installing banners and billboards in a health campaign. Health Educ. Res. 2019, 34, 532-541. [CrossRef] [PubMed]

144. Misagh, N. Designing and developing a citizen-oriented advertisement system based on the concept of geographic fence. Geofence 2020. [CrossRef]

145. Haidu, I.; Crăciun, A.I.; Lupău, C.; Şerban, C. Using GIS in Order to Detect the Optimal Areas for Dedicated Advertising Geogr. Tech. 2009, 40-49. Available online: https://www.researchgate.net/publication/236880396_USING_GIS_IN_ORDER_TO_ DETECT_THE_OPTIMAL_AREAS_FOR_DEDICATED_ADVERTISING (accessed on 9 December 2015).

146. Luke, D.; Esmundo, E.; Bloom, Y. Smoke signs: Patterns of tobacco billboard advertising in a metropolitan region. Tob. Control 2000, 9, 16-23. [CrossRef] [PubMed]

147. Hillier, A.; Cole, B.L.; Smith, T.E.; Yancey, A.K.; Williams, J.D.; Grier, S.A.; McCarthy, W.J. Clustering of unhealthy outdoor advertisements around child-serving institutions: A comparison of three cities. Health Place 2009, 15, 935-945. [CrossRef] [PubMed]

148. Malloy, L. Using Location-Based Information to Get More From Your Out-of-Home Advertising. AdSmart Blog. 2014. Available online: http:/ / www.intermap.com/adsmart-blog/2014/09/get-more-from-out-of-home-advertising (accessed on 12 December 2015).

149. Pelzer, P. Usefulness of planning support systems: A conceptual framework and an empirical illustration. Transp. Res. Part A Policy Pract. 2017, 104. [CrossRef]

150. Zigurs, I.; Buckland, B.K. A theory of task/technology fit and group support systems effectiveness. MIS Q. 1998, 22, 313-334. [CrossRef]

151. Hussnain, M.Q.; Waheed, A.; Wakil, K.; Tahir, A.; Pettit, C.; Pelizaro, C.; Jabbar, J.A. A Planning Support System to Aid Spatial Planning in Pakistan. In Proceedings of the 15th International Conference on Computers in Urban Planning and Urban Management, Adelaide, Australia, 11-14 July 2017.

152. Hussnain, M.Q.; Waheed, A.; Anjum, G.A.; Naeem, M.A.; Wakil, K.; Tahir, A.; Pettit, C.; Hussain, E. Application of the Online WhatIf? Planning Support System in Peri-urban Spatial Planning; Case study of Muzaffargarh, Pakistan. In Proceedings of the 24th International Conference on Urban Planning and Regional Development in the Information Society 2019, Karlsruhe, Germany, 2-4 April 2019; Volume 4, pp. 77-87.

153. Li, C.; Xu, C.; Li, X. A multi-criteria decision-making framework for site selection of distributed PV power stations along high-speed railway. J. Clean. Prod. 2020, 277, 124086. [CrossRef]

154. Saaty, T.L. Decision making with the analytic hierarchy process. Int. J. Serv. Sci. 2008, 1, 83. [CrossRef]

155. Belton, V. A comparison of the analytic hierarchy process and a simple multi-attribute value function. Eur. J. Oper. Res. 1986, 26, 7-21. [CrossRef]

156. Carver, S.J. Integrating multi-criteria evaluation with geographical information systems geographical information systems. Int. J. Geogr. Inf. Syst. 1991, 5, 321-339. [CrossRef]

157. Goepel, K.D. Implementing the analytic hierarchy process as a standard method for multi-criteria decision making in corporate enterprises-A new AHP excel template with multiple inputs. In Proceedings of the International Symposium on the Analytic Hierarchy Process, Kuala Lumpur, Malaysia, 23-26 June 2013. 
158. Kil, S.-H.; Lee, D.K.; Kim, J.-H.; Li, M.-H.; Newman, G. Utilizing the Analytic Hierarchy Process to Establish Weighted Values for Evaluating the Stability of Slope Revegetation based on Hydroseeding Applications in South Korea. Sustainability 2016, 8, 58. [CrossRef]

159. Huang, R.; Yeh, C. Development of an assessment framework for green highway construction. J. Chin. Instig. Eng. 2008, 31, 573-585. [CrossRef]

160. Franek, J.; Kresta, A. Judgment Scales and Consistency Measure in AHP. Procedia Econ. Financ. 2014, 12, 164-173. [CrossRef]

161. Mardani, A.; Jusoh, A.; Nor, K.M.D.; Khalifah, Z.; Zakwan, N.; Valipour, A. Multiple criteria decision-making techniques and their applications-A review of the literature from 2000 to 2014. Econ. Res. Istraz. 2015, 28, 516-571. [CrossRef]

162. Mohajeri, N.; Amin, G.R. Railway station site selection using analytical hierarchy process and data envelopment analysis. Comput. Ind. Eng. 2010, 59, 107-114. [CrossRef]

163. Beskese, A.; Demir, H.H.; Ozcan, H.K.; Okten, H.E. Landfill site selection using fuzzy AHP and fuzzy TOPSIS: A case study for Istanbul. Environ. Earth Sci. 2015, 73, 3513-3521. [CrossRef]

164. Noorollahi, E.; Fadai, D.; Shirazi, M.A.; Ghodsipour, S.H. Land suitability analysis for solar farms exploitation using GIS and fuzzy analytic hierarchy process (FAHP)—A case study of Iran. Energies 2016, 9, 643. [CrossRef]

165. Asakereh, A.; Soleymani, M.; Sheikhdavoodi, M.J. A GIS-based Fuzzy-AHP method for the evaluation of solar farms locations: Case study in Khuzestan province, Iran. Solar Energy 2017, 155, 342-353. [CrossRef]

166. Taibi, A.; Atmani, B. Combining Fuzzy AHP with GIS and Decision Rules for Industrial Site Selection. Int. J. Interact. Multim. Artif. Intell. 2017, 4, 60-69. [CrossRef]

167. Darani, S.K.; Eslami, A.A.; Jabbari, M.; Asefi, H. Parking Lot Site Selection Using a Fuzzy AHP-TOPSIS Framework in Tuyserkan, Iran. J. Urban Plan. Dev. 2018, 144, 04018022. [CrossRef]

168. Tsiko, R.G.; Haile, T.S. Integrating Geographical Information Systems, Fuzzy Logic and Analytical Hierarchy Process in Modelling Optimum Sites for Locating Water Reservoirs. A Case Study of the Debub District in Eritrea. Water 2011, 3, 254-290. [CrossRef]

169. Di Zio, S.; Rosas, J.D.C.; Lamelza, L. Real Time Spatial Delphi: Fast convergence of experts' opinions on the territory. Technol. Forecast. Soc. Chang. 2017, 115, 143-154. [CrossRef]

170. Gomez, J.E.A., Jr. The Billboardization of Metro Manila. Int. J. Urban Reg. Res. 2013, 37, 186-214. [CrossRef]

171. GoP. Punjab Local Government Act 2013; GoP: Lahore, Pakistan, 2013.

172. Jiang, H.; Yi, J.; Chen, S.; Zhu, X.; Wang, Z. A Novel RFID-Based Outdoor Billboard Management System. In Proceedings of the 2015 International Conference on Advanced Manufacturing and Industrial Application, Phuket, Thailand, 20-21 December 2015. [CrossRef]

173. Ke, X.; Li, J.; Liu, J.; Yu, Y. Design and implementation of billboards management system base on measurable streetview map. J. Geomat. 2015, 40, 71-73. [CrossRef]

174. Andrei, B. The automation of a sustainable billboard management system. In Proceedings of the 2013 8th International Symposium on Advanced Topics in Electrical Engineering (Atee), Bucharest, Romania, 23-25 May 2013; Available online: https: / /ieeexplore.ieee.org/abstract/document/6563490/ (accessed on 30 January 2021).

175. Mahabadi, M.; Mahabadi, S.; Shariaty, S. Method and system for providing management services to billboard owners and providing billboard availability data to billboard renters. U.S. Patent Application 10/876,154, 30 December 2004. Available online: https:/ / patents.google.com/patent/US20040267634A1/en (accessed on 30 January 2021). 